\title{
Bioactivation of Selective Estrogen Receptor Modulators (SERMs)
}

\author{
Tamara S. Dowers, Zhi-Hui Qin, Gregory R. J. Thatcher, and Judy L. Bolton * \\ Department of Medicinal Chemistry and Pharmacognosy (M/C 781), College of Pharmacy, \\ University of Illinois at Chicago, 833 S. Wood Street, Chicago, Illinois 60612-7231
}

\section{Introduction}

The drug tamoxifen, which opposes the action of estrogen in certain tissues and mimics its action in other tissues, has played a major role in the decline of breast cancer mortality rates over the past twenty years (1). This intriguing tissue-specific behavior was demonstrated in the National Surgical Adjuvant Breast and Bowel Project-sponsored Breast Cancer Prevention Trial (BCPT), which was launched in April of 1992. In the group of woman at high risk for breast cancer who were treated with tamoxifen, there was a remarkable $45 \%$ reduction in the incidence of breast cancer, demonstrating for the first time, that breast cancer cannot only be treated but also prevented (1). Such a positive outcome led researchers to release the results 14 months earlier than originally planned (1). The BCPT also demonstrated a reduced occurrence in bone fracture incidence (1). However, there was an increased incidence of endometrial cancer (33 cases versus 14 in the placebo group) (2,3). This troubling result demonstrates the crucial need of fully understanding the potential carcinogenic mechanisms of tamoxifen, as well as related selective estrogen receptor modulators (SERMs), as they are in wide spread use as prophylactic agents in high risk but otherwise healthy individuals.

The most widely recognized mechanism for the carcinogenicity of tamoxifen is estrogen receptor mediated hormonal activity (4). As tamoxifen has been shown to stimulate uterine growth and induce estrogen-like changes in the genital tract of humans and other animals (5, 6), it is likely that tamoxifen stimulates estrogen-responsive growth regulatory genes (7). The regulation of gene transcription may be largely responsible for the carcinogenic effects of tamoxifen in the endometrium; however, an alternative initiation mechanism could involve bioactivation of tamoxifen to form either redox-active or electrophilic metabolites, including a carbocation $(8,9)$, an $o$-quinone (10), and a quinone methide (11) (Scheme 1). These metabolites have the potential to act as chemical carcinogens by modifying critical cellular macromolecules $(12,13,14)$. A complete understanding of the relevant mechanisms of toxicity would allow for the design of new drugs which do not generate genotoxic or cytotoxic species while still maintaining their beneficial properties.

Synthetic ligands such as tamoxifen and the related compound, raloxifene, belong to a class of molecules termed "Selective Estrogen Receptor Modulators" (SERMs). This term signifies their ability to act as estrogen agonists in some tissues (bone, liver, and cardiovascular system), antagonists in other tissues (breast and brain), and mixed agonists/antagonists in the uterus. Tamoxifen has greater stimulatory activity in the uterus compared to that of raloxifene (15, 16,17 ) and the "Study of Tamoxifen and Raloxifene" (STAR) trial is currently underway to compare the safety and effectiveness of these two compounds for the prevention of breast cancer in post-menopausal women (18). Preliminary results of the STAR trial indicate that

\footnotetext{
*Address editorial correspondence to: Dr. Judy L. Bolton, Department of Medicinal Chemistry and Pharmacognosy (M/C 781), College of Pharmacy, University of Illinois at Chicago, 833 S. Wood Street, Chicago, IL, 60612-7231, FAX (312) 996-7107, E-mail: judyb@uic.edu
} 
raloxifene works just as well as tamoxifen at reducing breast cancer risk, but does not increase the risk of endometrial cancer (19). A great deal of effort is being expended toward improving tissue selectivity of SERMs so that they are optimized for preventing and treating breast cancer while alleviating menopausal symptoms. Specifically, our current understanding of estrogenic physiology suggests that the ideal SERM would display estrogen agonist activity in bone, cardiovascular tissue, and the central nervous system, with antagonist effects in uterus and breast tissue. As a result, this ideal SERM would enhance bone formation, improve lipid profiles, and provide neuroprotection, without increasing risk of estrogen-dependent cancers.

\subsection{Estrogen Receptor}

Estrogens put forth their regulatory effects by binding to estrogen receptors (ERs), which induces conformational changes in protein structure that allow for receptor dimerization and interaction with coactivator molecules (Scheme 2) $(20,21)$. The subsequent transcriptional activation of genes occurs either through the binding of liganded ERs directly to estrogen response elements (EREs) in gene promoters, or indirectly through binding to other transcription factors $(22,23,24,25,26,27,28,29)$.

ERs $\alpha$ and $\beta$ are members of the nuclear receptor superfamily of ligand-inducible transcription factors $(30,31)$. ER $\alpha$ is predominantly expressed in the breast, uterus, and vagina, whereas higher levels of ER $\beta$ relative to ER $\alpha$ are found in the central nervous system, cardiovascular system, gastrointestinal system, immune system, kidney, lungs, and bone (32). ER $\alpha$ regulates the differentiation and maintenance of neural, skeletal, cardiovascular, and reproductive tissues $(33,34)$. Compounds that modulate ER $\alpha$ transcriptional activity are used to treat osteoporosis, cardiovascular disease, and breast cancer $(35,36)$. The existence of distinct tissue expression profiles for ER $\alpha$ and ER $\beta$ suggests that tissues could be differentially targeted with receptor specific ligands (37). However, to date, the complete therapeutic utility of ER $\beta$-selective ligands remains unclear (37). Several research groups have employed highly selective ER $\beta$ ligands to probe the physiological role of this receptor $(37,38,39,40)$. For example, using the ER $\beta$ selective antagonist, ERB-041, Harris et al. demonstrated that this receptor might be a useful target of certain inflammatory diseases (40).

ER $\alpha$ and ER $\beta$ are $96 \%$ homologous in their DNA binding domains and 53\% identical in their ligand binding domains (LBDs) (41). All ER $\alpha$ ligands bind to the C-terminal LBD. The LBD recognizes numerous compounds differing in size, shape, and chemical properties (42). Ligands such as the endogenous $17 \beta$-estradiol $\left(\mathrm{E}_{2}\right)$ and the synthetic estrogen diethylstilbestrol (DES) are pure agonists, while others such as ICI-164,384 function as pure antagonists (42).

SERMs function as antagonists in specific tissue and promoter contexts (43). Two different activation factors (AFs) mediate the transcriptional activation of $\mathrm{ER} \alpha$; $\mathrm{AF}-1$ in the $\mathrm{N}$-terminus and AF-2 in the LBD. AF-1 activity is regulated by growth factors through the MAP kinase pathway (44), while AF-2 activity is regulated through ligand binding (45). Numerous structural studies suggest that ligands regulate AF-2 activity by altering the structure of the LBD. Comparison of the structures of unliganded nuclear receptor (NR) LBDs to those of agonist-bound LBDs suggests that an agonist-induced conformational change involving the repositioning of helix 12 is essential for AF-2 activity (46). The structures of the ER $\alpha$ LBD with $\mathrm{E}_{2}$ and raloxifene bound show that both ligands bind at the same site within the LBD, but each ligand induces a different conformation of helix 12 (47). The alteration of helix 12 by raloxifene partially buries residues necessary for AF- 2 activity, suggesting raloxifene and other antagonists block AF-2 function by disrupting the conformation of the AF-2 surface.

Several proteins associate in a ligand-dependent manner with the ERs (Scheme 2). These proteins are termed transcriptional coactivators because they enhance ligand-dependent transcriptional activation by the ER $\alpha$ and other NRs $(48,49)$. Coactivators SRC-1 and GRIP1 
bind to agonist-bound LBDs for the ER $\alpha$ (and other NRs) using the putative AF-2 interaction surface (50). Certain coactivators, such as SRC-1 and GRIP1, recognize agonist-bound NR LBDs through a short signature motif, LXXLL (where $\mathrm{L}$ is leucine and $\mathrm{X}$ is any amino acid), termed the NR box $(51,52,53,54)$. A crystal structure of agonist DES bound to the ER $\alpha$ LBD and a peptide derived from the NR box II region of the coactivator GRIP1 indicates that the peptide binds in a short $\alpha$ helix to a hydrophobic groove on the surface of the LBD (42). In contrast, the structure of ER $\alpha$ bound to 4-hydroxytamoxifen, the active metabolite of tamoxifen, reveals that helix 12 destroys the coactivator recognition site by imitating interactions of the NR box peptide with the LBD.

It is now understood that the pharmacology of estrogens relies not only on the ligand and the estrogen receptors but also on third parties, such as gene promoter elements and coregulatory proteins (55). The ERs can interact with target genes either by binding directly to DNA response elements or through indirect tethering to other DNA binding transcription factors. Taking all of these factors into account, there appears to be a number of combinatorial possibilities for achieving tissue and gene-specific regulation of SERMs. For example, Shang and Brown revealed that the agonism of tamoxifen could be specifically attributed to the coactivator SRC1, which is present at a higher concentration in uterine cells compared to mammary gland cells (29). Therefore, the agonistic activity of tamoxifen in the uterus is a result of the conformation of the ligand-receptor complex, the promoter context (tethered interaction instead of direct DNA binding), and the level of specific coactivator. This estrogenic activity could be a major contributor to tamoxifen's carcinogenic effects in the endometrium. However, there is a great deal of interest in additional carcinogenic mechanisms involving the bioactivation of tamoxifen to reactive metabolites.

\subsection{Bioactivation of SERMs}

There are at least four different classes of electrophilic metabolites that can be formed from SERMs; carbocations, quinone methides, diquinone methides, and $o$-quinones. The contribution of each electrophile to a particular SERM's metabolic profile depends on the structure and reactivity of the SERM. Cytochrome $\mathrm{P} 450$ can hydroxylate tamoxifen and related compounds (toremifene, droloxifene, and idoxifene) at the $\alpha$-position. Upon conjugation with sulfate and subsequent loss of the sulfate group, these SERMs form highly reactive carbocations which can react with DNA (Scheme 1) $(8,9)$; however, the detection of endometrial DNA-adducts in exposed women remains highly controversial $(56,57,58)$. The second bioactivation pathway is exemplified by the hydroxylation of tamoxifen by P450 to form a 4-hydroxylated metabolite, which can be further oxidized to a classical quinone methide (11) (Scheme 1). The SERM acolbifene is also converted by P450 to a diquinone methide (59) (Scheme 3). In addition, the SERMs raloxifene (Scheme 4) (60) and desmethylated arzoxifene (DMA) (61) can be converted to diquinone methides. The raloxifene metabolite has recently been implicated in the inhibition of P450 3A4 and the alkylation of many other liver microsomal proteins $(62,63)$. The fourth bioactivation pathway for SERMs involves $o$-quinone formation and has been implicated in tamoxifen-mediated protein binding (Scheme 1) (64, 65). Clearly, the structure of a compound determines the formation, reactivity, and selectivity of the reactive intermediates formed. Understanding the influence of SERM structure on these properties would provide the valuable insight necessary for the design of new SERMs.

\section{Classes of Selective Estrogen Receptor Modulators}

SERMs are often categorized as second-, third-, and fourth-generation suggesting a progressive development in a process intended to improve the beneficial effects while reducing the harmful side effects associated with the earlier SERMs (41). This general classification of SERMs serves little purpose because the numbering is highly subjective and does not describe a logical transition from first to fourth. The prototype SERM, tamoxifen, and its derivatives, toremifene, 
droloxifene, and, idoxifene, belong to the chemical class of triphenylethylene compounds (Figure 1A). The second-generation SERM raloxifene and the third-generation SERM arzoxifene are benzothiophene compounds (Figure 1B), while the fourth-generation SERM alcolbifene is a benzopyran derivative (Figure 1C). As a result, for the purpose of this review, it is preferable to classify SERMs according to chemical family.

\subsection{Triphenylethylene SERMs}

SERMs of the triphenylethylene type have been extensively used for the treatment of hormonedependent breast cancer. Tamoxifen is an oral drug first used in metastatic breast cancer in the early 1970s (66). Large clinical trials were initiated in the late 1970s and early 1980s to test the drug's role as adjuvant therapy in early stage breast cancer. Observations of marked decreases in the development of contralateral breast cancer among tamoxifen recipients suggested potential for the drug in chemoprevention of breast cancer, and a large clinical trial to test the efficacy of tamoxifen in prevention of invasive breast cancer among women at increased risk was implemented in the United States in 1992 (66). There are a number of reports that have emphasized an increased incidence of premalignant and neoplastic endometrial changes $(67,68)$ which questioned the risk-benefit ratio for this medication $(69,70)$. In addition, several studies in animal models have raised concern over the safety of chronic treatment with this drug (71). For example, tamoxifen induces hepatocarcinomas (71), frequent and specific mutations in the $p 53$ tumor suppresser gene (72), and mammary tumors (73) in rats.

Triphenylethylene derivatives (Figure 1A), with small structural changes compared to tamoxifen, are also in use for the treatment of breast cancer. Droloxifene, which has a 3hydroxy substituent, has antiestrogenic activity in vitro which is equivalent or slightly greater than that of tamoxifen (74). Interestingly, unlike tamoxifen, droloxifene does not appear to induce liver tumors in rats and no DNA adducts have been detected from this analog (75). Similarly, the 4-iodo derivative of tamoxifen, idoxifene, has comparable antiestrogenic potency to tamoxifen without generating hepatocarcinogenic effects in rodents $(76,77)$. Toremifene also displays antiestrogenic activity in the mammary gland and its beneficial effects on bone mineral density and lipid profiles are similar to that of tamoxifen (41). However, also like tamoxifen, toremifene has stimulatory effects in the endometrium and is presently only used in postmenopausal women with metastatic breast cancer (41). Toremifene was found to form DNA adducts in rats, although the levels were significantly lower for toremifene compared to that of tamoxifen (78). The annual hazard rate (per 1,000 patients/year) of developing endometrial carcinoma in patients on toremifene therapy is 1.14 , which is much less compared to that of tamoxifen (2.0) (79). It should be noted however, that in the absence of extensive epidemiology studies of all of these tamoxifen derivatives, the potential remains for genotoxic/cytotoxic effects to surface in the future.

\subsection{Benzothiophene SERMs}

Greater optimism has surrounded the profile of benzothiophene SERMs (Figure 1B) (80). Much of the enthusiasm relates to the fact that these drugs appear devoid of any agonist activity in the endometrium, while at the same time appearing to be potent antiestrogens in the breast and agonists in bone $(15,16,17)$. A benzothiophene SERM, raloxifene, is in clinical use for the prevention and treatment of postmenopausal osteoporosis and is currently in the STAR trial, the largest breast cancer chemoprevention trial ever conducted (18). Very recent results of the STAR trial indicate that regular use of raloxifene works just as well as tamoxifen at reducing breast cancer risk in postmenopausal women at high risk, but appears to cause less of the dangerous side effects associated with tamoxifen use (19). Raloxifene is not being pursued in chemotherapy of breast cancer due to low efficacy in women with advanced breast cancer (81). The Raloxifene Use for The Heart trial (RUTH) is also currently being conducted to investigate whether raloxifene will decrease the incidence of coronary events and the risk 
of invasive breast cancer in postmenopausal women with heart disease or at risk of heart attack (82). Preliminary results of this trial indicate that raloxifene does not decrease or increase the risk of coronary events but could potentially reduce the risk of invasive breast cancer (82).

Arzoxifene is another member of the benzothiophene SERM family, and it has been reported to have a more favorable therapeutic and safety profile as compared to raloxifene $(83,84,85$, 86). In addition, unlike tamoxifen, arzoxifene acts as an estrogen antagonist in the uterus (87). In a phase II trial of arzoxifene in advanced endometrial cancer, arzoxifene showed high antitumor activity (88). Until very recently, the use of arzoxifene versus tamoxifen as a firstline therapy in metastatic breast cancer was being studied in a multicenter phase III trial (89). However, the trial was terminated early after initial results suggested that arzoxifene is inferior to tamoxifen with respect to time to progression (a measure of time from when the disease is treated until the disease starts to get worse) (89).

Despite the mixed results obtained from in vivo studies, several cell-based assays have demonstrated arzoxifene's efficacy (90). Both arzoxifene and its active metabolite desmethylated arzoxifene (DMA) were shown to bind the ER with high affinity and inhibit estrogen dependent growth of MCF-7 breast cancer cells (90). When assayed for the inhibition of proliferation of these cells, Suh et al. reported arzoxifene $\left(\mathrm{IC}_{50}, 0.4 \mathrm{nM}\right)$ to be more potent than tamoxifen $\left(\mathrm{IC}_{50}, 480 \mathrm{nM}\right)$ or its active metabolite, 4-hydroxytamoxifen $\left(\mathrm{IC}_{50}, 1.2 \mathrm{nM}\right)$, with DMA being the most potent agent tested $\left(\mathrm{IC}_{50}, 0.05 \mathrm{nM}\right)$ and raloxifene being equal to that of arzoxifene (90).

\subsection{Benzopyran SERMs}

The so-called fourth generation SERM, acolbifene (Figure 1C), is an active benzopyran derivative of EM-800. Acolbifene is the most potent antiestrogen in terms of inhibition of both $\mathrm{ER} \alpha$ and $\mathrm{ER} \beta$ (91), and EM-800 is an extremely potent inhibitor of the proliferation of breast and endometrial cancer cells in culture $(92,93)$. EM-800 has also been shown to prevent the growth of estrogen-stimulated tumor xenografts in athymic mice (94) and prevent bone loss and cardiovascular disease in rats (95).

\section{Bioactivation Pathways}

Herein, we discuss four different electrophilic metabolites that can be formed from the SERMs shown in Figure 1. The triphenylethylene SERMs can form highly reactive carbocations, which have been implicated in DNA binding $(8,9,56,57,58,96)$. The second bioactivation pathway involves oxidation of tamoxifen and acolbifene to classical quinone methides (11). In addition, raloxifene (60), DMA (61), and acolbifene (59) can be converted to diquinone methides. The fourth bioactivation pathway involves $o$-quinone formation, which is generally a minor pathway for SERMs. In the following sections, we review these bioactivation pathways along with an example of formation of more complex reactive intermediates formed from SERMs.

\subsection{Carbocations}

Hydroxylation of tamoxifen at the $\alpha$-carbon is predominately carried out by P450s 3A, 2D6, $2 \mathrm{C} 9,1 \mathrm{~A} 1,1 \mathrm{~A} 2$, and 1B1 (97). Following $O$-sulfonation, $\alpha$-hydroxytamoxifen reacts preferentially with the exocyclic amino group of guanine in DNA to form two cis and two trans epimers of $\alpha$-( $\mathrm{N}_{2}$-deoxyguanosyl)tamoxifen (98). Shibutani et al. reported the detection of these adducts in the endometrial tissue of 8 out of 16 women treated with tamoxifen (9), and more recently Kim et al. observed the same adducts in primary cultured human endometrial explants incubated with $\alpha$-hydroxytamoxifen (99). However, due in part to the high concentrations of $\alpha$-hydroxytamoxifen that Kim et al. used in their experiments ( 25 and 100 $\mu \mathrm{M})$, several research groups have questioned the validity of this data $(56,100)$. As $\alpha$ - 
hydroxytamoxifen is a very minor metabolite of tamoxifen, it is most likely present at very low concentrations (ca. $0.2 \mathrm{nM}$ ) (101). In a separate study, Sharma et al. reported the use of high performance liquid chromatography (HPLC) with online postcolumn photochemical activation and fluorescence detection to detect the presence of (E)- $\alpha$ - $\left(\mathrm{N}_{2}\right.$-deoxyguanosyl) tamoxifen in human endometrial explants incubated with tamoxifen (102). These results were also highly controversial due to the ambiguous characterization of the tamoxifen-DNA adducts (58). Specifically, this method could potentially lead to erroneous detection of tamoxifen-DNA adducts as the ability to distinguish between these adducts and noncovalently bound metabolites depends on the resolution of the HPLC system (100). To address this issue, two additional techniques were employed by Beland $e t$ al. to assay for tamoxifen-DNA adducts in human endometrial explants (58). Both HPLC coupled with electrospray ionization tandem mass spectrometry and ${ }^{32} \mathrm{P}$-postlabeling analysis were used and tamoxifen-DNA adducts were not detected with either method. The authors conclude that although these data are in conflict with that reported by Sharma et al., they are consistent with the limited amount of $\alpha$ hydroxytamoxifen produced in human tissue and, more importantly the small amount of $\alpha$ hydroxytamoxifen that is sulfonated (58).

Toremifene is significantly less potent than tamoxifen at causing DNA adduct formation in rats (78). Interestingly, human P450 3A4 was found to $\alpha$-hydroxylate toremifene approximately six times faster than tamoxifen (103). However, $\alpha$-hydroxytoremifene is not a good substrate for human hydroxysteroid sulfotransferase (hHST) (104). Therefore, $O$ sulfonation does not occur to a significant extent with this metabolite (104). Furthermore, the resulting toremifene $\alpha$-sulfate is not as reactive with DNA compared with the tamoxifen $\alpha$ sulfate (79). It has been proposed that this low reactivity may be brought on by steric hinderance caused by the bulky chlorine atom on the ethyl moiety of toremifene (79). Additionally, the electron-withdrawing chlorine atom may make elimination of the $\alpha$-sulfate group less effective and in turn, slow the formation of the reactive carbocation that reacts with DNA (105).

Although further experimental and clinical studies are required, the use of toremifene may be accompanied with less of the toxic effects associated with tamoxifen use in breast cancer patients and women receiving chemoprevention (79).

\subsection{Classical Quinone Methides}

The second bioactivation pathway involves oxidation of SERMs to quinone methides. Quinone methides are reactive metabolites of 4-alkylphenols and are most likely responsible for their cytotoxic effects $(106,107,108)$. Like all reactive intermediates, the selectivity of a quinone methide depends on its rate of formation as well as its reactivity. Quinone methides differ structurally from quinones in that one of the carbonyl oxygens is replaced by a methylene or substituted methylene group. This renders the quinone methide a much more reactive electrophile with a reduced capacity for redox cycling $(107,108)$. Therefore, quinone methides generally react in biological systems via non-enzymatic Michael additions. With simple quinone methides, these reactions produce benzylic adducts of peptides, proteins, and nucleic acids $(107,108,109)$. Theoretically, quinone methides can be characterized as resonancestabilized carbocations $(110,111)$, due to the important contribution of the charged aromatic resonance form. This electron deficiency at the methylene carbon, along with inter- or intramolecular factors which stabilize this resonance structure, lead to increased reactivity with cellular nucleophiles.

A relatively stable quinone methide is produced by initial P450-catalyzed aromatic hydroxylation of tamoxifen to yield 4-hydroxytamoxifen, followed by a P450-catalyzed direct 2-electron oxidation (Scheme 1) (112). This quinone methide is extremely long lived at physiological $\mathrm{pH}$ and temperature $\left(t_{1 / 2}=3 \mathrm{~h}\right)$ (Table 1) (11), most likely due to stabilization imposed by the two aryl substituents and the $\pi$ system of the additional vinyl group. The vinyl 
substituent alone can decrease the reactivity of $o$-methoxyquinone methides by a factor of 100 (113) and an aryl substituent leads to a 230-fold increase in stability relative to quinone methides with an unsubstituted exocyclic methylene group (109). This $\pi$-stabilization, in addition to steric factors, completely changes the chemistry of the 4-hydroxytamoxifen quinone methide. Most quinone methides react instantaneously with GSH, whereas the 4hydroxytamoxifen quinone methide has a half-life in the presence of GSH of approximately 4 $\min$ (11). This reaction with GSH is reversible as the GSH conjugates slowly decompose to regenerate the quinone methide (11). Tamoxifen-GSH conjugates were detected in liver microsomal incubations with 4-hydroxytamoxifen; however, none were observed in incubations with breast cancer cells (MCF-7) (11).

Toremifene also undergoes oxidative metabolism to form a quinone methide. The 4hydroxytoremifene quinone methide has a half-life at physiological $\mathrm{pH}$ and temperature of 1 $\mathrm{h}$, while its half-life in the presence of GSH is approximately $6 \mathrm{~min}$ (Table 1) (11). The 4hydroxytoremifene quinone methide reacts with two molecules of GSH and loses chlorine to yield the corresponding di-GSH conjugate (11). This reaction mechanism likely involves an electrophilic episulfonium ion intermediate, which could contribute to the potential cytotoxicity of toremifene (11). In microsomal incubations, 4-hydroxytoremifene was metabolized to di-GSH conjugates at 3 times the rate of 4-hydroxytamoxifen, although no GSH conjugates were observed in the incubations with MCF-7 cells (11). These data imply that the quinone methide may not play a significant role in the cytotoxicity or genotoxicity of tamoxifen and toremifene.

Interestingly, it has been shown that the polymorphic P450 isozyme 2D6 primarily catalyzes 4-hydroxylation of tamoxifen in the human liver (114). This result has been confirmed using human liver microsomes and expressed P450s (115), as well as by molecular modeling studies (116). There also appears to be a contribution from P450 2C9 and P450 3A4 as tamoxifen 4hydroxylases in some individuals. As 5-10\% of the population have defects in P450 2D6 (117) and there are several allelic variants of 2C9 (118), it is possible that these individuals will not experience the effects, if any, of the tamoxifen quinone methide. Alternatively, breast cancer patients with defective 2D6 or 2C9 who are receiving tamoxifen chemotherapy, are less likely to respond to the drug since 4-hydroxytamoxifen is 100 times more potent as an estrogen receptor antagonist $(119,120)$.

Acolbifene is also metabolized to form a classical quinone methide (Scheme 3) (59). The classical quinone methide is formed by oxidation at the $\mathrm{C}-17$ methyl group and has a half life of $32 \mathrm{~s}$ at physiological $\mathrm{pH}$ and temperature (59). This is considerably shorter than that of the 4-hydroxytamoxifen quinone methide ( $3 \mathrm{~h}$ ) (11) and indicates that the acolbifene quinone methide is an electrophile of intermediate stability (Table 1). The acolbifene quinone methide reacts with GSH to form five mono-GSH conjugates and five di-GSH conjugates (59). In addition, incubations of acolbifene with either tyrosinase or rat or human liver microsomes also yield the classical quinone methide-GSH conjugates (59).

In addition to reaction with GSH, the acolbifene quinone methide was determined to react with deoxynucleosides. In contrast to what was observed with raloxifene and DMA, the acolbifene quinone methide formed adducts with each of the four deoxynucleosides, with one of the major adducts resulting from reaction with the exocylic amino group of adenine (59). LC-MS-MS analysis of incubations of the DMA diquinone methide with deoxynucleosides yielded a negligible amount of one deoxyguanosine adduct (61), while no adducts were observed in incubations of deoxynucleosides with the raloxifene diquinone methide (unpublished results). Experiments were also performed to assess the toxicity of acolbifene, DMA, and raloxifene in the S30 cell line. DNA damage detected by the comet assay showed that both acolbifene and DMA induced more DNA damage than raloxifene (59). Both the stability and reactivity of the 
quinone methides might account for this difference. However, as these experiments were performed at very high SERM concentrations $(\mu \mathrm{M})$, the results are not indicative of cellular induction of DNA damage in vivo.

\subsection{Diquinone Methides}

The third mechanism of bioactivation is the formation of diquinone methides, which occurs with the benzothiophene SERMs raloxifene (60) and arzoxifene (61), and the benzopyran SERM acolbifene (59). Raloxifene undergoes rapid absorption, extensive first-pass glucuronidation, and enterohepatic cycling after oral administration, resulting in an absolute bioavailability of just $2 \%(121,122)$. Raloxifene can be bioactivated by rat and human liver microsomes to an electrophilic diquinone methide and in a very minor pathway to $o$-quinones (Scheme 4) $(60,63)$. The raloxifene diquinone methide is relatively short-lived, with a half-life of less than $1 \mathrm{~s}$ at physiological $\mathrm{pH}$ and temperature (Table 1) (60). This highly reactive metabolite has the potential to contribute to cytotoxicity likely through alkylation of proteins in vivo.

Raloxifene is associated with decreases in cytochrome $\mathrm{P} 450$ aromatase activity in human colon carcinoma cells (123) and is an irreversible inhibitor of P450 3A4 (63). As reported by Chen et al., the P450 inhibition in human liver microsomes was NADPH- and preincubation timedependent, indicating that metabolism was required for inactivation. The $K_{\mathrm{I}}$ and $k_{\text {inact }}$ values were about $9.9 \mu \mathrm{M}$ and $6 \mathrm{~min}^{-1}$, respectively (63). The authors found that the loss of P450 activity was partially attenuated by the addition of GSH to the incubation mixture. Furthermore, raloxifene-GSH conjugates were detected in the incubation mixtures, derived from either a raloxifene arene oxide and/or a raloxifene diquinone methide. As the GSH adducts were almost completely abolished when the liver microsomes were pretreated with ketoconozole or an antiP450 3A4 IgG, the bioactivation of raloxifene is most likely catalyzed by the 3A4 isoform (63). This suggests that bioactivation of raloxifene by P450 3A4 results in electrophilic intermediates that covalently modify the enzyme.

To identify microsomal proteins covalently modified by raloxifene metabolites, we synthesized a novel raloxifene covert oxidatively activated tag (COATag) in which the SERM was linked to biotin (Figure 2A) (62). In this study, the raloxifene COATag allowed identification of covalently modified proteins by immunoblotting and LC-MS-MS analysis (Figure 2B). The COATag was unreactive toward the selected model protein, purified human glutathione-Stransferase (hGST PI-1); however, upon co-incubation with tyrosinase, a covalently COATagged hGST protein adduct was isolated and identified by mass spectrometric analysis as modified at cys-47 (62). Similarly, the formation of COATagged proteins on incubation with rat liver microsomes was dependent upon the concentration of NADPH. These COATagged proteins were quantified and identified by SDS-PAGE and western blot analysis. Four major bands were observed in the blots from microsomal incubations, for which peptide mass spectrometry maps were obtained using in-gel digestion, followed by MALDI-TOF or ESI mass spectral analysis of the resulting peptide mixtures. Cytosolic glucose regulated protein $(78 \mathrm{kDa}, \mathrm{GRP78} / \mathrm{BiP})$, protein disulfide isomerase isozyme A4 precursor $(72 \mathrm{kDa}$, ERp72), protein disulfide isomerase isozyme A1 (57 kDa, PDIA1), protein disulfide isomerase isozyme A3 (58 kDa, ER-60) and microsomal glutathione S-transferase, (17 kDa, mGST1) were identified as targets (62). These data show that raloxifene produces a highly reactive intermediate that modifies tissue microsomal proteins with a low degree of selectivity, which might be an expected feature of a reactive intermediate with a relatively short lifetime.

DMA is a structural analogue of raloxifene in which the carbonyl group of raloxifene has been replaced by an ether linkage (Figure 1B). Arzoxifene is oxidatively desmethylated in vivo to yield DMA, an active metabolite that is a more potent ligand for both ER $\alpha$ and ER $\beta$ than both arzoxifene and raloxifene (61). However, it is unclear as to how much DMA is actually formed 
from arzoxifene, since in women, reported DMA plasma concentrations are highly variable (124). The methoxy group of arzoxifene is designed both to reduce glucuronidation and increase the $\mathrm{C} \log \mathrm{P}$ value and is proposed to limit brain penetration. The intended effect of these modifications is to increase the bioavailability of the active drug relative to raloxifene (125). DMA can be oxidized to a diquinone methide, in the presence of rat or human liver microsomes (61). The half-life of the DMA diquinone methide was found to be $15 \mathrm{~s}$ at physiological $\mathrm{pH}$ and temperature (61), which indicates that it is an electrophile of intermediate stability, along with the acolbifene quinone methide discussed above (Table 1).

Given the need to develop new SERMs with attenuated toxicity and increased bioavailability while maintaining their beneficial effects, we synthesized a fluorinated DMA derivative ( $4^{\prime} \mathrm{F}$ DMA) which is incapable of forming a diquinone methide (Figure 1B). 4'F-DMA showed similar ER binding affinity compared to that of DMA, whereas the antiestrogenic activity was 10 -fold lower for than that of DMA; however, comparable to that of raloxifene (61). No GSH conjugates were detected in microsomal incubations with 4'F-DMA in the presence of GSH. Furthermore, DMA significantly decreased the GSH levels within 30 min, whereas 4'F-DMA had no effect on GSH levels (61). 4'F-DMA also induced much less DNA damage compared to DMA in cryopreserved rat hepatocytes. Phase I and phase II metabolism and toxicological behavior of DMA and 4'F-DMA were also compared using cryopreserved rat hepatocytes. Two DMA GSH conjugates, two DMA glucuronide conjugates, and one DMA sulfate conjugate were detected in incubations of DMA with rat hepatocytes. In contrast, 4'F-DMA did not yield GSH conjugates in incubations with rat hepatocytes, demonstrating that 4'-fluoro substitution of DMA blocked quinoid formation at the cellular level (61). Moreover, 4'F-DMA was observed to form two-fold less glucuronide conjugates relative to DMA in hepatocytes, which might be expected by the absence of the $4^{\prime} \mathrm{OH}$ group, since in raloxifene this is the major site of glucuronidation.

Intestinal glucuronidation of raloxifene is the major contributor to the presystemic clearance of raloxifene in vivo (126). Therefore, microsomes prepared from human small intestine were used to further evaluate the glucuronidation of DMA and 4'F-DMA. 4'F-DMA formed fourfold less glucuronide conjugates as compared to DMA in the incubation with human small intestinal microsomes in the presence of UDP-glucuronic acid (61). In human intestinal Caco-2 cells, a $24 \mathrm{~h}$ incubation of 4'F-DMA afforded thirty-fold less glucuronide conjugates and fivefold less sulfate conjugates compared with that of DMA (61). Therefore, 4'F-DMA should demonstrate improved bioavailability relative to DMA and raloxifene.

The ER-dependent activity of 4'F-DMA was examined by measuring ERE-luciferase activity in transiently transfected MCF-7 cells and Ishikawa cells (61). None of the SERMs studied showed estrogenic activity in either cell line; however, estradiol-induced luciferase activity was significantly antagonized by raloxifene, DMA, 4'F-DMA, and the pure antiestrogen, ICI 182780, in both cell lines (61). 4'F-DMA showed less antiestrogenic activity as compared to DMA, but comparable activity compared to raloxifene and ICI 182780 in both cell lines. Furthermore, 4'F-DMA antagonized the actions of estradiol in the MCF-7 cell proliferation assay without itself showing estrogenic activity and again, the antiestrogenicity of 4'F-DMA was comparable to raloxifene and ICI 182780. Taken together, these data suggest that 4'FDMA represents a promising SERM with comparable antiestrogenic activity to raloxifene, but improved metabolic stability and an attenuated potential for toxicity compared to the current benzothiophene SERMs.

Acolbifene is also metabolized through a minor pathway leading to a diquinone methide (Scheme 3) (59). The acolbifene diquinone methide results from the oxidation of two phenol substituents (59). Like the classical quinone methide, the diquinone methide reacts with GSH to form five mono-GSH conjugates and five di-GSH conjugates, although the majority of the 
GSH adducts are formed by reaction of the classical quinone methide with GSH (59). Furthermore, incubations of acolbifene with either tyrosinase or rat or human liver microsomes also yield the classical quinone methide-GSH conjugates (59). Therefore, the formation of the acolbifene classical quinone methide might represent the major toxic pathway relative to that of the diquinone methide.

\section{4.o-Quinones}

In addition to the formation of the tamoxifen carbocation and quinone methide, tamoxifen can be oxidized to the corresponding $o$-quinone (127). Both tamoxifen and 4-hydroxytamoxifen can be metabolized to 3,4-dihydroxytamoxifen (Scheme 1). As catechols are readily oxidized to $o$-quinones by a variety of oxidative enzymes, metal ions, and in some cases molecular oxygen, it is possible that alkylation/oxidation of cellular macromolecules by tamoxifen $o$ quinone could contribute to the toxic effects of tamoxifen. However, as this is a minor pathway for tamoxifen, its contributions to tamoxifen's overall toxicity are most likely minimal.

The $o$-quinone formed from 3,4-dihydroxytamoxifen has a half-life of approximately $80 \mathrm{~min}$ under physiological conditions (Table 1) (10). Incubation of rat liver microsomes with 3,4dihydroxytamoxifen in the presence of GSH produced several $o$-quinone GSH conjugates, which were also observed in the incubations with breast cancer cells (MCF-7). Incubation of 3,4-dihydroxytamoxifen $o$-quinone with deoxynucleosides produced four thymidine and four deoxyguanosine adducts, which may have derived from the addition at different sites on the $o$-quinone ring and/or $E, Z$ isomers of tamoxifen skeleton (10). In addition to acting as electrophilic Michael addition acceptors to form conjugates with GSH and deoxynucleosides, the $o$-quinones can also undergo redox cycling with the semiquinone radicals to generate superoxide anion radicals, which is mediated through cytochrome $\mathrm{P} 450$ and $\mathrm{P} 450$ reductase (109). The reaction of superoxide anion radicals with hydrogen peroxide (formed enzymatically or via spontaneous dismutation of superoxide anion radical in the presence of trace amounts of iron or other transition metals) yields hydroxyl radicals. Hydroxyl radicals are powerful oxidizing agents that may be responsible for the damage to essential cellular macromolecules. The detection of DNA single strand breaks in incubations of 3,4dihydroxytamoxifen with various breast cancer cell lines suggests that the 3,4dihydroxytamoxifen $o$-quinone could cause oxidative DNA damage through redox cycling with semiquinone radicals (128).

Like tamoxifen, the 4-hydroxylation also represents a major phase I metabolic pathway of toremifene $(129,130)$. In rat liver microsomal incubations, both 4-hydroxytoremifene and droloxifene were metabolized by P450s to the corresponding catechol metabolites 3,4dihydroxytoremifene and 3,4-dihydroxydroloxifene to yield $o$-quinone derived GSH conjugates. In the 4-hydroxytoremifene incubation, the amount of quinone methide derived GSH conjugates was higher than that of $o$-quinone derived GSH conjugates (131), possibly because the $\beta-\mathrm{Cl}$ substitution lowered the energy barrier for $\alpha$ - hydrogen atom abstraction, easing the 2-electron oxidation pathway leading to the 4-hydroxytoremifene quinone methide. Compared with 3,4-dihydroxytamoxifen $o$-quinone, the 3,4-dihydroxytoremifene $o$-quinone showed higher reactivity toward deoxynucleosides. The toremifene-o-quinone reacted with all four deoxynucleosides to form the corresponding adducts at physiological $\mathrm{pH}$ and temperature. Three of the adducts were detected in incubations with thymidine, five in incubations with deoxyguanosine, two in incubations with deoxyadenosine, and eight in incubations with deoxycytosine (131). When incubated with breast cancer cell lines, 3,4-dihydroxytoremifene also caused DNA single strand breaks (128). Furthermore, different amounts of DNA damage were observed in ER positive cell lines and ER negative cell lines, suggesting the ERs might play a role in this process (128). 
Raloxifene is metabolized by rat or human liver microsomes to an electrophilic diquinone methide and an $o$-quinone (Scheme 4 ) which can be trapped by GSH to form mono-and/or diGSH conjugates (60). Hydroxylated catechols such as 7-hydroxyraloxifene and 3'-

hydroxyraloxifene were also detected in the incubation mixture. The half-life of raloxifene diquinone methide is less than $1 \mathrm{~s}$; however, the half-life of the raloxifene 6,7-o-quinone is 69 min (Table 1). The stability offered by 6,7-o-quinone implies that it may be more toxic than the raloxifene diquinone methide. However, as this pathway is a minor one for raloxifene, physiological concentrations of the raloxifene $o$-quinone are probably insufficient to induce toxicity.

Very recently, Eli Lilly reported the discovery of two new SERMs for the potential treatment of uterine leiomyoma (LY2066948) and hot flushes (LSN2021310) (Figure 3). LY2066948 has a methyl sulfone group at 4' position, which renders this molecule less susceptible to metabolic conjugation and limits brain penetration. In several in vivo studies in rat models, LSN2021310 increased bone mineral density, lowered serum cholesterol, exhibited minimal uterine agonist activity, and displayed dose-dependent activity of hot flush efficacy. However, both LY2066948 and LSN2021310 share the same naphthol structure with equilenin (Figure 3 ), the equine estrogen present in hormone replacement therapy preparations. The presence of an unsaturated B-ring generally leads to exclusive 4-hydroxylation, which, in turn leads to the formation of a highly reactive $o$-quinone (132). It is known that both P450s 1A1 and 1B1 catalyze the 4-hydroxylation of equilenin (Figure 3) (133) and the catechol formed will autoxidize to the 3,4-o-quinone (134). Catalyzed by $\mathrm{NAD}(\mathrm{P}) \mathrm{H}, \mathrm{P} 450$ reductase, or quinone reductase, the $o$-quinone readily enters into a redox couple with the semiquinone radical, resulting in the generation of reactive oxygen species (ROS) (Scheme 5) (135). In in vitro studies, the 3,4-equilenin $o$-quinone, semiquinone, and ROS displayed high reactivity to nucleosides and DNA, leading to the formation of unusual cyclic nucleoside adducts, oxidative damage to DNA nucleobases, DNA single strand breaks, and apurinic sites(135,136,137). In a rat model, 4-hydroxyequilenin was shown to cause DNA damage in vivo (138). In addition, 4-hydroxyequilenin can inhibit detoxification enzymes of the cell, such as glutathione Stransferase (GST) (139) and catechol O-methyltransferase (COMT) (140,141). Since the naphthol structure is responsible for the carcinogenic bioactivation of equilenin, it is likely that LY2066948 and LSN2021310 are also metabolized to 3,4-o-quinones and will display similar carcinogenic potential.

\subsection{Miscellaneous Bioactivation Pathways}

The final bioactivation pathways we will discuss includes the formation of quinone metabolites, an iminium ion, and an aldehyde from two recently discovered SERMs (Dihydrobenzoxathiin compounds I and II in Scheme 6 and 7). Dihydrobenzoxathiin I was synthesized as a selective ER $\alpha$ antagonist and its bioactivation in both human liver microsomes and recombinant P450 3A4 has been studied extensively by Zhang et al. (142). This compound is metabolized to a hydroquinone and an $o$-quinone (Scheme 6). The hydroquinone is obtained from oxidative cleavage of the dihydrobenzoxathiin moiety and has the potential to undergo oxidation to the corresponding quinone. Both the $o$-quinone and the hydroquinone could contribute to the observed protein binding. In addition, since a dinitrile compound (bis-cyano adduct) was detected when the incubation was performed in the presence of sodium cyanide, an iminium ion intermediate derived from the piperidine side chain of $(\mathbf{I})$ is most likely formed in the incubation. Therefore, compound (I) is subject to at least three bioactivation pathways, two of them leading to quinone metabolites, and the third producing an iminium ion.

Extensive studies of these benzoxathiin compounds led to the discovery of (II), which has a $3^{\prime}-\mathrm{OH}$ instead of a 4'-OH, and the substitution of the piperidine side chain with a pyrolidine moiety. Compared with (I), the new compound exhibited optimal in vitro and in vivo potency 
and selectivity toward ER $\alpha$. Scheme 7 shows the reactive metabolites obtained in the incubation with human liver microsomes and recombinant P4503A4. The major metabolite was a biphenyl hydroquinone derivative, which came from the rearrangement of the parent compound. In addition, the dihydrobenzoxathiin oxidative cleavage metabolite was also a hydroquinone and both of these metabolites could potentially covalently modify proteins via reactive quinone intermediates. An aldehyde was also detected and has to potential to form Schiff base adducts with proteins. Co-incubation with $\mathrm{N}$-acetylcysteine (NAc) led to four NAc adducts, providing evidence that dihydrobenzoxathiin (II) also underwent bioactivation to form reactive quinone species. Since, the degree of protein covalent binding by (II) was much lower than (I), (II) was chooses as the lead compound.

\section{Concluding Remarks}

The foreseen long-term clinical use of SERMs and risk of carcinogenesis require study of potential mechanisms of toxicity including covalent modification of cellular macromolecules. Adducts with glutathione, proteins, nucleosides, and DNA have been reported for many SERMs in vitro and in some cases in vivo. Several different bioactivation mechanisms are involved in converting SERMs to reactive intermediates, all of which can be initiated via oxidation by cytochrome P450. These bioactivation pathways include carbocation formation, the classical quinone methide and diquinone methide pathways, and $o$-quinone formation. The triphenylethylene SERMs, such as the prototype tamoxifen, are hydroxylated by P450 at the $\alpha$-position. Upon conjugation with sulfate and subsequent loss of the sulfate group, these molecules form highly reactive carbocations which have the potential to react with DNA ( 8 , 9). However, tamoxifen-DNA adducts in endometrial tissue have only been detected with some ambiguity $(56,99)$. Therefore, the physiological relevance of this mechanism have been questioned by several research groups $(56,57,58)$.

The second bioactivation pathway is exemplified by the hydroxylation of tamoxifen by P450 to form 4-hydroxylated metabolites, which can be further oxidized to classical quinone methides (11). The amount of the tamoxifen quinone methide produced as well as its stability suggests it is unlikely to result in cytotoxicity or genotoxicity (11). However, acolbifene is also converted to a classical quinone methide, which may be its major pathway of bioactivation (59). In addition, raloxifene (60), DMA (61), and acolbifene (59) can all be converted to diquinone methides. The raloxifene diquinone methide has recently been implicated in the inhibition of P450 3A4 (63), and the alkylation of many other liver microsomal proteins (62).

The acolbifene quinone methide has a half-life that is considerably shorter (32 s) (59) than that of the 4-hydroxytamoxifen quinone methide $(3 \mathrm{~h})(11)$, but longer than that of the raloxifene diquinone methide (1 s) (Table 1) (60). According to Thompson et al., quinone methides with half-lives in the range of $10 \mathrm{~s}$ to $10 \mathrm{~min}$ have time to diffuse away from the site of formation to react with cellular nucleophiles (107). These quinone methides are more likely to cause toxicity compared to more reactive ones that will react immediately with another quinone methide, solvent, oxygen, or the enzyme responsible for their formation (59). According to this hypothesis, the acolbifene quinone methide can be considered an electrophile of intermediate stability and therefore might be a contributor to the potential genotoxicity or cytotoxicity of acolbifene through depletion of GSH and modification of cellular macromolecules (59).

The Thompson hypothesis is persuasive in its simplicity and would have the benefit of being a predictive tool of use in drug discovery. However, the observation that the short-lived raloxifene diquinone methide is able to escape its oxidative enzyme to modify a variety of proteins, although is does so with a low degree of selectivity, clearly indicates that the original hypothesis must be modified. This evolution can only be effected through further studies on 
the reaction mechanisms and targets of reactive intermediates formed from oxidative metabolism of SERMs and related compounds.

The fourth bioactivation pathway for SERMs involves $o$-quinone formation and has been implicated in tamoxifen-mediated protein binding $(64,65)$. This is generally a minor pathway for SERMs but might be a major pathway for $\beta$-napthol compounds. Finally, quinone metabolites, an iminium ion, and an aldehyde formed from two recently discovered SERMs (Dihydrobenzoxathiin compounds I and II in Scheme 5 and 6) have all been implicated in protein binding (142).

Understanding how the structure of SERMs influences the formation and reactivity of reactive intermediates is an important tool for the discovery of potential new SERMs that are not associated with genotoxic or cytotoxic effects. A complete understanding of these toxic metabolites is necessary as SERMs are already in wide spread use as prophylactic agents in high risk but otherwise healthy individuals.

\section{Acknowledgements}

This work is supported by NIH Grants CA102590, CA79870 and CA73638.

\section{Glossary}

$\mathrm{AF}$, activation factor

BCPT, National Surgical Adjuvant Breast and Bowel Project-sponsored Breast Cancer Prevention Trial

COATag, covert oxidatively activated tag

COMT, catechol- $O$-methyltransferase

DES, diethylstilbestrol

DMA, desmethylated arzoxifene

$\mathrm{E}_{2}, 17 \beta$-estradiol

ER, estrogen receptor

ER-60, protein disulfide isomerase isozyme A3

ERE, estrogen response element

ERp72, protein disulfide isomerase isozyme A4 precursor

ESI, electrospray ionization

4'F-DMA, 4-fluorodesmethylated arzoxifene

GRIP1, glutamate receptor interacting protein 1

GRP78/BiP, cytosolic glucose regulated protein

GST, glutathione-S-transferase

hGST PI-1, human glutathione-S-transferase

hHST, human hydroxysteroid sulfotransferase

LBD, ligand binding domain

MALDI-TOF, matrix-assisted laser desorption ionization-time of flight

MAP, mitogen activated protein

mGST1, microsomal glutathione S-transferase

$\mathrm{NR}$, nuclear receptor

PDIA1, protein disulfide isomerase isozyme A1

ROS, reactive oxygen species

RUTH trial, Raloxifene Use for The Heart trial

SERM, Selective Estrogen Receptor Modulator

SRC-1, steroid receptor coactivator-1

STAR trial, Study of Tamoxifen and Raloxifene trial. 


\section{References}

(1). Smigel K. Breast Cancer Prevention Trial shows major benefit, some risk. J. Natl. Cancer Inst 1998;90:647-648. [PubMed: 9586658]

(2). Fisher B, Costantino JP, Wickerham DL, Redmond CK, Kavanah M, Cronin WM, Vogel V, Robidoux A, Dimitrov N, Atkins J, Daly M, Wieand S, Tan-Chiu E, Ford L, Wolmark N. Tamoxifen for prevention of breast cancer: report of the National Surgical Adjuvant Breast and Bowel Project P-1 Study. J. Natl. Cancer Inst 1998;90:1371-1388. [PubMed: 9747868]

(3). Jordan VC, Morrow M. Tamoxifen, raloxifene, and the prevention of breast cancer. Endocr. Rev 1999;20:253-278. [PubMed: 10368771]

(4). Henderson BE, Ross R, Bernstein L. Estrogens as a cause of human cancer: the Richard and Hinda Rosenthal Foundation award lecture. Cancer Res 1988;48:246-253. [PubMed: 2825969]

(5). Friedl A, Jordan VC. What do we know and what don't we know about tamoxifen in the human uterus. Breast Cancer Res. Treat 1994;31:27-39. [PubMed: 7981454]

(6). Cohen I, Rosen DJ, Shapira J, Cordoba M, Gilboa S, Altaras MM, Yigael D, Beyth Y. Endometrial changes with tamoxifen: comparison between tamoxifen-treated and nontreated asymptomatic, postmenopausal breast cancer patients. Gynecol. Oncol 1994;52:185-190. [PubMed: 8314137]

(7). Roy RN, Gerulath AH, Cecutti A, Bhavnani BR. Effect of tamoxifen treatment on the endometrial expression of human insulin-like growth factors and their receptor mRNAs. Mol. Cell. Endocrinol 2000;165:173-178. [PubMed: 10940495]

(8). Shibutani S, Suzuki N, Terashima I, Sugarman SM, Grollman AP, Pearl ML. Tamoxifen-DNA adducts detected in the endometrium of women treated with tamoxifen. Chem. Res. Toxicol 1999;12:646-653. [PubMed: 10409405]

(9). Shibutani S, Ravindernath A, Suzuki N, Terashima I, Sugarman SM, Grollman AP, Pearl ML. Identification of tamoxifen-DNA adducts in the endometrium of women treated with tamoxifen. Carcinogenesis 2000;21:1461-1467. [PubMed: 10910945]

(10). Zhang F, Fan PW, Liu X, Shen L, van Breeman RB, Bolton JL. Synthesis and reactivity of a potential carcinogenic metabolite of tamoxifen: 3,4-dihydroxytamoxifen-o-quinone. Chem. Res. Toxicol 2000;13:53-62. [PubMed: 10649967]

(11). Fan PW, Zhang F, Bolton JL. 4-Hydroxylated metabolites of the antiestrogens tamoxifen and toremifene are metabolized to unusually stable quinone methides. Chem. Res. Toxicol 2000;13:4552. [PubMed: 10649966]

(12). Bolton JL. Quinoids, quinoid radicals, and phenoxyl radicals formed from estrogens and antiestrogens. Toxicology 2002;177:55-65. [PubMed: 12126795]

(13). Bolton JL, Trush MA, Penning TM, Dryhurst G, Monks TJ. Role of quinones in toxicology. Chem. Res. Toxicol 2000;13:135-160. [PubMed: 10725110]

(14). Kim SY, Suzuki N, Laxmi YR, Shibutani S. Genotoxic mechanism of tamoxifen in developing endometrial cancer. Drug Metab. Rev 2004;36:199-218. [PubMed: 15237851]

(15). Katzenellenbogen BS, Montano MM, Ediger TR, Sun J, Ekena K, Lazennec G, Martini PG, McInerney EM, Delage-Mourroux R, Weis K, Katzenellenbogen JA. Estrogen receptors: selective ligands, partners, and distinctive pharmacology. Recent Prog. Horm. Res 2000;55:163-193. [PubMed: 11036937]discussion 194-165

(16). Katzenellenbogen BS, Sun J, Harrington WR, Kraichely DM, Ganessunker D, Katzenellenbogen JA. Structure-function relationships in estrogen receptors and the characterization of novel selective estrogen receptor modulators with unique pharmacological profiles. Ann. N. Y. Acad. Sci 2001;949:6-15. [PubMed: 11795381]

(17). McKenna NJ, O’Malley BW. An issue of tissues: divining the split personalities of selective estrogen receptor modulators. Nat. Med 2000;6:960-962. [PubMed: 10973303]

(18). Rhodes DJ, Hartmann LC, Perez EA. Breast cancer prevention trials. Curr. Oncol. Rep 2000;2:558565. [PubMed: 11122893]

(19). Phillips, C. NCI Cancer Bulletin. National Cancer Institute; 2006. STAR Results: Raloxifene as Effective as Tamoxifen, Better Safety Profile; p. 1-2.

(20). McDonnell DP, Norris JD. Connections and regulation of the human estrogen receptor. Science 2002;296:1642-1644. [PubMed: 12040178] 
(21). McKenna NJ, Lanz RB, O’Malley BW. Nuclear receptor coregulators: cellular and molecular biology. Endocr. Rev 1999;20:321-344. [PubMed: 10368774]

(22). Kushner PJ, Agard DA, Greene GL, Scanlan TS, Shiau AK, Uht RM, Webb P. Estrogen receptor pathways to AP-1. J. Steroid. Biochem. Mol. Biol 2000;74:311-317. [PubMed: 11162939]

(23). Kushner PJ, Agard D, Feng WJ, Lopez G, Schiau A, Uht R, Webb P, Greene G. Oestrogen receptor function at classical and alternative response elements. Novartis. Found. Symp 2000;230:20-26. [PubMed: 10965500]discussion 27-40

(24). Watanabe T, Inoue S, Hiroi H, Orimo A, Kawashima H, Muramatsu M. Isolation of estrogenresponsive genes with a CpG island library. Mol. Cell. Biol 1998;18:442-449. [PubMed: 9418891]

(25). Dubik D, Shiu RP. Mechanism of estrogen activation of c-myc oncogene expression. Oncogene 1992;7:1587-1594. [PubMed: 1630819]

(26). Umayahara Y, Kawamori R, Watada H, Imano E, Iwama N, Morishima T, Yamasaki Y, Kajimoto Y, Kamada T. Estrogen regulation of the insulin-like growth factor I gene transcription involves an AP-1 enhancer. J. Biol. Chem 1994;269:16433-16442. [PubMed: 8206951]

(27). Shang Y, Hu X, DiRenzo J, Lazar MA, Brown M. Cofactor dynamics and sufficiency in estrogen receptor-regulated transcription. Cell 2000;103:843-852. [PubMed: 11136970]

(28). Smith CL, O’Malley BW. Coregulator function: a key to understanding tissue specificity of selective receptor modulators. Endocr. Rev 2004;25:45-71. [PubMed: 14769827]

(29). Shang Y, Brown M. Molecular determinants for the tissue specificity of SERMs. Science 2002;295:2465-2468. [PubMed: 11923541]

(30). Tsai MJ, O’Malley BW. Molecular mechanisms of action of steroid/thyroid receptor superfamily members. Annu. Rev. Biochem 1994;63:451-486. [PubMed: 7979245]

(31). Beato M, Herrlich P, Schutz G. Steroid hormone receptors: many actors in search of a plot. Cell 1995;83:851-857. [PubMed: 8521509]

(32). Kuiper GG, Carlsson B, Grandien K, Enmark E, Haggblad J, Nilsson S, Gustafsson JA. Comparison of the ligand binding specificity and transcript tissue distribution of estrogen receptors alpha and beta. Endocrinology 1997;138:863-870. [PubMed: 9048584]

(33). Korach KS. Insights from the study of animals lacking functional estrogen receptor. Science 1994;266:1524-1527. [PubMed: 7985022]

(34). Smith EP, Boyd J, Frank GR, Takahashi H, Cohen RM, Specker B, Williams TC, Lubahn DB, Korach KS. Estrogen resistance caused by a mutation in the estrogen-receptor gene in a man. N. Engl. J. Med 1994;331:1056-1061. [PubMed: 8090165]

(35). Gradishar WJ, Jordan VC. Clinical potential of new antiestrogens. J. Clin. Oncol 1997;15:840-852. [PubMed: 9053512]

(36). Jordan VC. Antiestrogenic action of raloxifene and tamoxifen: today and tomorrow. J. Natl. Cancer Inst 1998;90:967-971. [PubMed: 9665143]

(37). Manas ES, Unwalla RJ, Xu ZB, Malamas MS, Miller CP, Harris HA, Hsiao C, Akopian T, Hum WT, Malakian K, Wolfrom S, Bapat A, Bhat RA, Stahl ML, Somers WS, Alvarez JC. Structurebased design of estrogen receptor-beta selective ligands. J. Am. Chem. Soc 2004;126:15106-15119. [PubMed: 15548008]

(38). Hillisch A, Peters O, Kosemund D, Muller G, Walter A, Schneider B, Reddersen G, Elger W, Fritzemeier KH. Dissecting physiological roles of estrogen receptor alpha and beta with potent selective ligands from structure-based design. Mol. Endocrinol 2004;18:1599-1609. [PubMed: 15105439]

(39). Gungor T, Chen Y, Golla R, Ma Z, Corte JR, Northrop JP, Bin B, Dickson JK, Stouch T, Zhou R, Johnson SE, Seethala R, Feyen JH. Synthesis and characterization of 3-arylquinazolinone and 3arylquinazolinethione derivatives as selective estrogen receptor beta modulators. J. Med. Chem 2006;49:2440-2455. [PubMed: 16610787]

(40). Harris HA, Albert LM, Leathurby Y, Malamas MS, Mewshaw RE, Miller CP, Kharode YP, Marzolf J, Komm BS, Winneker RC, Frail DE, Henderson RA, Zhu Y, Keith JC Jr. Evaluation of an estrogen receptor-beta agonist in animal models of human disease. Endocrinology 2003;144:4241-4249. [PubMed: 14500559]

(41). Shang Y. Molecular mechanisms of oestrogen and SERMs in endometrial carcinogenesis. Nat. Rev. Cancer 2006;6:360-368. [PubMed: 16633364] 
(42). Shiau AK, Barstad D, Loria PM, Cheng L, Kushner PJ, Agard DA, Greene GL. The structural basis of estrogen receptor/coactivator recognition and the antagonism of this interaction by tamoxifen. Cell 1998;95:927-937. [PubMed: 9875847]

(43). Grese TA, Sluka JP, Bryant HU, Cullinan GJ, Glasebrook AL, Jones CD, Matsumoto K, Palkowitz AD, Sato M, Termine JD, Winter MA, Yang NN, Dodge JA. Molecular determinants of tissue selectivity in estrogen receptor modulators. Proc. Natl. Acad. Sci. U. S. A 1997;94:14105-14110. [PubMed: 9391160]

(44). Kato S, Endoh H, Masuhiro Y, Kitamoto T, Uchiyama S, Sasaki H, Masushige S, Gotoh Y, Nishida E, Kawashima H, Metzger D, Chambon P. Activation of the estrogen receptor through phosphorylation by mitogen-activated protein kinase. Science 1995;270:1491-1494. [PubMed: 7491495]

(45). Kumar V, Green S, Stack G, Berry M, Jin JR, Chambon P. Functional domains of the human estrogen receptor. Cell 1987;51:941-951. [PubMed: 3690665]

(46). Moras D, Gronemeyer H. The nuclear receptor ligand-binding domain: structure and function. Curr. Opin. Cell. Biol 1998;10:384-391. [PubMed: 9640540]

(47). Brzozowski AM, Pike AC, Dauter Z, Hubbard RE, Bonn T, Engstrom O, Ohman L, Greene GL, Gustafsson JA, Carlquist M. Molecular basis of agonism and antagonism in the oestrogen receptor. Nature 1997;389:753-758. [PubMed: 9338790]

(48). Horwitz KB, Jackson TA, Bain DL, Richer JK, Takimoto GS, Tung L. Nuclear receptor coactivators and corepressors. Mol. Endocrinol 1996;10:1167-1177. [PubMed: 9121485]

(49). Glass CK, Rose DW, Rosenfeld MG. Nuclear receptor coactivators. Curr. Opin. Cell Biol 1997;9:222-232. [PubMed: 9069256]

(50). Feng W, Ribeiro RC, Wagner RL, Nguyen H, Apriletti JW, Fletterick RJ, Baxter JD, Kushner PJ, West BL. Hormone-dependent coactivator binding to a hydrophobic cleft on nuclear receptors. Science 1998;280:1747-1749. [PubMed: 9624051]

(51). Heery DM, Kalkhoven E, Hoare S, Parker MG. A signature motif in transcriptional co-activators mediates binding to nuclear receptors. Nature 1997;387:733-736. [PubMed: 9192902]

(52). Torchia J, Rose DW, Inostroza J, Kamei Y, Westin S, Glass CK, Rosenfeld MG. The transcriptional co-activator p/CIP binds CBP and mediates nuclear-receptor function. Nature 1997;387:677-684. [PubMed: 9192892]

(53). Ding XF, Anderson CM, Ma H, Hong H, Uht RM, Kushner PJ, Stallcup MR. Nuclear receptorbinding sites of coactivators glucocorticoid receptor interacting protein 1 (GRIP1) and steroid receptor coactivator 1 (SRC-1): multiple motifs with different binding specificities. Mol. Endocrinol 1998;12:302-313. [PubMed: 9482670]

(54). Le Douarin B, Nielsen AL, Garnier JM, Ichinose H, Jeanmougin F, Losson R, Chambon P. A possible involvement of TIF1 alpha and TIF1 beta in the epigenetic control of transcription by nuclear receptors. Embo. J 1996;15:6701-6715. [PubMed: 8978696]

(55). Katzenellenbogen BS, Katzenellenbogen JA. Biomedicine. Defining the "S" in SERMs. Science 2002;295:2380-2381. [PubMed: 11923515]

(56). Beland FA, Marques MM, Gamboa da Costa G, Phillips DH. Tamoxifen-DNA adduct formation in human endometrium. Chem. Res. Toxicol 2005;18:1507-1509. [PubMed: 16533012] author reply 1509-1511

(57). Carmichael PL, Sardar S, Crooks N, Neven P, Van Hoof I, Ugwumadu A, Bourne T, Tomas E, Hellberg P, Hewer AJ, Phillips DH. Lack of evidence from HPLC 32P-post-labelling for tamoxifenDNA adducts in the human endometrium. Carcinogenesis 1999;20:339-342. [PubMed: 10069474]

(58). Beland FA, Churchwell MI, Hewer A, Phillips DH, daCosta GG, Marques MM. Analysis of tamoxifen-DNA adducts in endometrial explants by MS and 32P-postlabeling. Biochem. Biophys. Res. Commun 2004;320:297-302. [PubMed: 15219826]

(59). Liu J, Liu H, van Breemen RB, Thatcher GR, Bolton JL. Bioactivation of the selective estrogen receptor modulator acolbifene to quinone methides. Chem. Res. Toxicol 2005;18:174-182. [PubMed: 15720121]

(60). Yu L, Liu H, Li W, Zhang F, Luckie C, van Breemen RB, Thatcher GR, Bolton JL. Oxidation of raloxifene to quinoids: potential toxic pathways via a diquinone methide and o-quinones. Chem. Res. Toxicol 2004;17:879-888. [PubMed: 15257612] 
(61). Liu H, Liu J, van Breemen RB, Thatcher GR, Bolton JL. Bioactivation of the selective estrogen receptor modulator desmethylated arzoxifene to quinoids: 4'-fluoro substitution prevents quinoid formation. Chem. Res. Toxicol 2005;18:162-173. [PubMed: 15720120]

(62). Liu J, Li Q, Yang X, van Breemen RB, Bolton JL, Thatcher GR. Analysis of Protein Covalent Modification by Xenobiotics Using a Covert Oxidatively Activated Tag: Raloxifene Proof-ofPrinciple Study. Chem. Res. Toxicol 2005;18:1485-1496. [PubMed: 16167842]

(63). Chen Q, Ngui JS, Doss GA, Wang RW, Cai X, DiNinno FP, Blizzard TA, Hammond ML, Stearns RA, Evans DC, Baillie TA, Tang W. Cytochrome P450 3A4-mediated bioactivation of raloxifene: irreversible enzyme inhibition and thiol adduct formation. Chem. Res. Toxicol 2002;15:907-914. [PubMed: 12119000]

(64). Dehal SS, Kupfer D. Cytochrome P-450 3A and 2D6 catalyze ortho hydroxylation of 4hydroxytamoxifen and 3-hydroxytamoxifen (droloxifene) yielding tamoxifen catechol: involvement of catechols in covalent binding to hepatic proteins. Drug. Metab. Dispos 1999;27:681-688. [PubMed: 10348797]

(65). Dehal SS, Kupfer D. Evidence that the catechol 3,4-Dihydroxytamoxifen is a proximate intermediate to the reactive species binding covalently to proteins. Cancer Res 1996;56:1283-1290. [PubMed: 8640815]

(66). Fisher B, Redmond C. New perspective on cancer of the contralateral breast: a marker for assessing tamoxifen as a preventive agent. J. Natl. Cancer Inst 1991;83:1278-1280. [PubMed: 1832192]

(67). Killackey MA, Hakes TB, Pierce VK. Endometrial adenocarcinoma in breast cancer patients receiving antiestrogens. Cancer Treat. Rep 1985;69:237-238. [PubMed: 3971394]

(68). Fornander T, Rutqvist LE, Cedermark B, Glas U, Mattsson A, Silfversward C, Skoog L, Somell A, Theve T, Wilking N, et al. Adjuvant tamoxifen in early breast cancer: occurrence of new primary cancers. Lancet 1989;1:117-120. [PubMed: 2563046]

(69). Cohen CJ, Rahaman J. Endometrial cancer. Management of high risk and recurrence including the tamoxifen controversy. Cancer 1995;76:2044-2052. [PubMed: 8634998]

(70). Nease RF Jr. Ross JM. The decision to enter a randomized trial of tamoxifen for the prevention of breast cancer in healthy women: an analysis of the tradeoffs. Am. J. Med 1995;99:180-189. [PubMed: 7625423]

(71). King CM. Tamoxifen and the induction of cancer. Carcinogenesis 1995;16:1449-1454. [PubMed: 7614676]

(72). Vancutsem PM, Lazarus P, Williams GM. Frequent and specific mutations of the rat p53 gene in hepatocarcinomas induced by tamoxifen. Cancer Res 1994;54:3864-3867. [PubMed: 8033108]

(73). Fendel KCZ. Role of tamoxifen in the induction of hormone-independent rat mammary tumors. Cancer Res 1992:235-237. [PubMed: 1727383]S.J.

(74). Roos W, Oeze L, Loser R, Eppenberger U. Antiestrogenic action of 3-hydroxytamoxifen in the human breast cancer cell line MCF-7. J. Natl. Cancer Inst 1983;71:55-59. [PubMed: 6575210]

(75). White IN, de Matteis F, Davies A, Smith LL, Crofton-Sleigh C, Venitt S, Hewer A, Phillips DH. Genotoxic potential of tamoxifen and analogues in female Fischer F344/n rats, DBA/2 and C57BL/ 6 mice and in human MCL-5 cells. Carcinogenesis 1992;13:2197-2203. [PubMed: 1473224]

(76). Pace P, Jarman M, Phillips D, Hewer A, Bliss J, Coombes RC. Idoxifene is equipotent to tamoxifen in inhibiting mammary carcinogenesis but forms lower levels of hepatic DNA adducts. Br. J. Cancer 1997;76:700-704. [PubMed: 9310233]

(77). Johnston SR, Riddler S, Haynes BP, A'Hern R, Smith IE, Jarman M, Dowsett M. The novel antioestrogen idoxifene inhibits the growth of human MCF-7 breast cancer xenografts and reduces the frequency of acquired anti-oestrogen resistance. Br. J. Cancer 1997;75:804-809. [PubMed: 9062399]

(78). White IN, Martin EA, Mauthe RJ, Vogel JS, Turteltaub KW, Smith LL. Comparisons of the binding of [14C]radiolabelled tamoxifen or toremifene to rat DNA using accelerator mass spectrometry. Chem. Biol. Interact 1997;106:149-160. [PubMed: 9366900]

(79). Kim SY, Suzuki N, Laxmi YR, Shibutani S. Genotoxic mechanism of tamoxifen in developing endometrial cancer. Drug. Metab. Rev 2004;36:199-218. [PubMed: 15237851]

(80). Johnston SR. Endocrine manipulation in advanced breast cancer: recent advances with SERM therapies. Clin. Cancer Res 2001;7:4376s-4387s. [PubMed: 11916228]discussion 4411s-4412s 
(81). Gradishar W, Glusman J, Lu Y, Vogel C, Cohen FJ, Sledge GW Jr. Effects of high dose raloxifene in selected patients with advanced breast carcinoma. Cancer 2000;88:2047-2053. [PubMed: 10813716]

(82). Eli Lilly and Company. Lilly announces preliminary coronary and breast cancer. Results from Raloxifene Use for The Heart (RUTH) study. Apr 12. 2006 IssuedAvailable online at http://newsroom.lilly.com/ReleaseDetail.cfm?ReleaseID=192692

(83). Dardes RC, Bentrem D, O'Regan RM, Schafer JM, Jordan VC. Effects of the new selective estrogen receptor modulator $\mathrm{LY} 353381 . \mathrm{HCl}$ (Arzoxifene) on human endometrial cancer growth in athymic mice. Clin. Cancer. Res 2001;7:4149-4155. [PubMed: 11751515]

(84). McMeekin DS, Gordon A, Fowler J, Melemed A, Buller R, Burke T, Bloss J, Sabbatini P. A phase II trial of arzoxifene, a selective estrogen response modulator, in patients with recurrent or advanced endometrial cancer. Gynecol. Oncol 2003;90:64-69. [PubMed: 12821343]

(85). Baselga J, Llombart-Cussac A, Bellet M, Guillem-Porta V, Enas N, Krejcy K, Carrasco E, Kayitalire L, Kuta M, Lluch A, Vodvarka P, Kerbrat P, Namer M, Petruzelka L. Randomized, double-blind, multicenter trial comparing two doses of arzoxifene (LY353381) in hormone-sensitive advanced or metastatic breast cancer patients. Ann. Oncol 2003;14:1383-1390. [PubMed: 12954577]

(86). Chan S. Arzoxifene in breast cancer. Eur. J. Cancer 2002;38(Suppl 6):S55-56. [PubMed: 12409075]

(87). Vernon MW. Experimental endometriosis in laboratory animals as a research model. Prog. Clin. Biol. Res 1990;323:49-60. [PubMed: 2406756]

(88). Thomas W, Burke MD, Cheryl L. Walker. Arzoxifene as therapy for endometrial cancer. Gynecol. Oncol 2003;90:S40-S46. [PubMed: 12928005]

(89). Munster PN. Arzoxifene: the development and clinical outcome of an ideal SERM. Expert Opin. Investig. Drugs 2006;15:317-326.

(90). Suh N, Glasebrook AL, Palkowitz AD, Bryant HU, Burris LL, Starling JJ, Pearce HL, Williams C, Peer C, Wang Y, Sporn MB. Arzoxifene, a new selective estrogen receptor modulator for chemoprevention of experimental breast cancer. Cancer Res 2001;61:8412-8415. [PubMed: 11731420]

(91). Gauthier S, Caron B, Cloutier J, Dory YL, Favre A, Larouche D, Mailhot J, Ouellet C, Schwerdtfeger A, Leblanc G, Martel C, Simard J, Merand Y, Belanger A, Labrie C, Labrie F. (S)-(+)-4-[7-(2,2dimethyl-1-oxopropoxy)-4-methyl-2-[4-[2-(1-piperidinyl)-ethoxy]phenyl]-2H-1-benzopyran-3yl]-phenyl 2,2-dimethylpropanoate (EM-800): a highly potent, specific, and orally active nonsteroidal antiestrogen. J. Med. Chem 1997;40:2117-2122. [PubMed: 9216828]

(92). Simard J, Labrie C, Belanger A, Gauthier S, Singh SM, Merand Y, Labrie F. Characterization of the effects of the novel non-steroidal antiestrogen EM-800 on basal and estrogen-induced proliferation of T-47D, ZR-75-1 and MCF-7 human breast cancer cells in vitro. Int. J. Cancer 1997;73:104-112. [PubMed: 9334816]

(93). Simard J, Sanchez R, Poirier D, Gauthier S, Singh SM, Merand Y, Belanger A, Labrie C, Labrie F. Blockade of the stimulatory effect of estrogens, OH-tamoxifen, OH-toremifene, droloxifene, and raloxifene on alkaline phosphatase activity by the antiestrogen EM-800 in human endometrial adenocarcinoma Ishikawa cells. Cancer Res 1997;57:3494-3497. [PubMed: 9270018]

(94). Couillard S, Gutman M, Labrie C, Belanger A, Candas B, Labrie F. Comparison of the effects of the antiestrogens EM-800 and tamoxifen on the growth of human breast ZR-75-1 cancer xenografts in nude mice. Cancer Res 1998;58:60-64. [PubMed: 9426058]

(95). Luo S, Labrie C, Belanger A, Labrie F. Effect of dehydroepiandrosterone on bone mass, serum lipids, and dimethylbenz(a)anthracene-induced mammary carcinoma in the rat. Endocrinology 1997;138:3387-3394. [PubMed: 9231792]

(96). Jordan VC. Selective estrogen receptor modulation: concept and consequences in cancer. Cancer Cell 2004;5:207-213. [PubMed: 15050912]

(97). Sharma M, Shubert DE, Lewis J, McGarrigle BP, Bofinger DP, Olson JR. Biotransformation of tamoxifen in a human endometrial explant culture model. Chem. Biol. Interact 2003;146:237-249. [PubMed: 14642736]

(98). Kim SY, Laxmi YR, Suzuki N, Ogura K, Watabe T, Duffel MW, Shibutani S. Formation of tamoxifen-DNA adducts via O-sulfonation, not O-acetylation, of alpha-hydroxytamoxifen in rat and human livers. Drug. Metab. Dispos 2005;33:1673-1678. [PubMed: 16099924] 
(99). Kim SY, Suzuki N, Laxmi YR, McGarrigle BP, Olson JR, Sharma M, Shibutani S. Formation of tamoxifen-DNA adducts in human endometrial explants exposed to alpha-hydroxytamoxifen. Chem. Res. Toxicol 2005;18:889-895. [PubMed: 15892583]

(100). Brown K, Carmichael PL. "Antioxidant inhibits tamoxifen-DNA adducts in endometrial explant culture”. Biochem. Biophys. Res. Commun 2003;310:1039. [PubMed: 14559219]Correspondence regarding $\mathrm{M}$. Sharma et al.

(101). Poon GK, Walter B, Lonning PE, Horton MN, McCague R. Identification of tamoxifen metabolites in human Hep G2 cell line, human liver homogenate, and patients on long-term therapy for breast cancer. Drug. Metab. Dispos 1995;23:377-382. [PubMed: 7628304]

(102). Sharma M, Shubert DE, Rodabaugh KJ, McGarrigle BP, Vezina CM, Bofinger DP, Olson JR. Antioxidant inhibits tamoxifen-DNA adducts in endometrial explant culture. Biochem. Biophys. Res. Commun 2003;307:157-164. [PubMed: 12849995]

(103). Kim SY, Suzuki N, Santosh Laxmi YR, Rieger R, Shibutani S. Alpha-hydroxylation of tamoxifen and toremifene by human and rat cytochrome P450 3A subfamily enzymes. Chem. Res. Toxicol 2003;16:1138-1144. [PubMed: 12971802]

(104). Shibutani S, Ravindernath A, Terashima I, Suzuki N, Laxmi YR, Kanno Y, Suzuki M, Apak TI, Sheng JJ, Duffel MW. Mechanism of lower genotoxicity of toremifene compared with tamoxifen. Cancer Res 2001;61:3925-3931. [PubMed: 11358807]

(105). Kuramochi H. Conformational studies and electronic structures of tamoxifen and toremifene and their allylic carbocations proposed as reactive intermediates leading to DNA adduct formation. J. Med. Chem 1996;39:2877-2886. [PubMed: 8709121]

(106). Thompson DC, Thompson JA, Sugumaran M, Moldeus P. Biological and toxicological consequences of quinone methide formation. Chem. Biol. Interact 1993;86:129-162. [PubMed: 8448810]

(107). Thompson DC, Perera K, Krol ES, Bolton JL. o-Methoxy-4-alkylphenols that form quinone methides of intermediate reactivity are the most toxic in rat liver slices. Chem. Res. Toxicol 1995;8:323-327. [PubMed: 7578916]

(108). Peter MG. Chemical Modifications of Bio-Polymers by Quinones and Quinone Methides. Angew. Chem. Int. Edit 1989;28:555-570.

(109). Monks TJ, Hanzlik RP, Cohen GM, Ross D, Graham DG. Quinone chemistry and toxicity. Toxicol. Appl. Pharmacol 1992;112:2-16. [PubMed: 1733045]

(110). Richard JP, Amyes TL, Bei L, Stubblefield V. The Effect of Beta-Fluorine Substituents on the Rate and Equilibrium-Constants for the Reactions of Alpha-Substituted 4-Methoxybenzyl Carbocations and on the Reactivity of a Simple Quinone Methide. J. Am. Chem. Soc 1990;112:9513-9519.

(111). Hulbert PB, Grover PL. Chemical rearrangement of phenol-epoxide metabolites of polycyclic aromatic hydrocarbons to quinone-methides. Biochem. Biophys. Res. Commun 1983;117:129-134. [PubMed: 6661217]

(112). Potter GA, McCague R, Jarman M. A mechanistic hypothesis for DNA adduct formation by tamoxifen following hepatic oxidative metabolism. Carcinogenesis 1994;15:439-442. [PubMed: 8118925]

(113). Bolton JL, Comeau E, Vukomanovic V. The influence of 4-alkyl substituents on the formation and reactivity of 2-methoxy-quinone methides: evidence that extended pi-conjugation dramatically stabilizes the quinone methide formed from eugenol. Chem. Biol. Interact 1995;95:279-290. [PubMed: 7728898]

(114). Dehal SS, Kupfer D. CYP2D6 catalyzes tamoxifen 4-hydroxylation in human liver. Cancer Res 1997;57:3402-3406. [PubMed: 9270005]

(115). Crewe HK, Ellis SW, Lennard MS, Tucker GT. Variable contribution of cytochromes P450 2D6, $2 \mathrm{C} 9$ and $3 \mathrm{~A} 4$ to the 4-hydroxylation of tamoxifen by human liver microsomes. Biochem. Pharmacol 1997;53:171-178. [PubMed: 9037249]

(116). Wiseman H, Lewis DF. The metabolism of tamoxifen by human cytochromes $\mathrm{P} 450$ is rationalized by molecular modelling of the enzyme-substrate interactions: potential importance to its proposed anti-carcinogenic/carcinogenic actions. Carcinogenesis 1996;17:1357-1360. [PubMed: 8681455] 
(117). Kroemer HK, Eichelbaum M. "It's the genes, stupid". Molecular bases and clinical consequences of genetic cytochrome P450 2D6 polymorphism. Life Sci 1995;56:2285-2298. [PubMed: 7791516]

(118). Wilkinson GR, Guengerich FP, Branch RA. Genetic polymorphism of S-mephenytoin hydroxylation. Pharmacol. Ther 1989;43:53-76. [PubMed: 2675129]

(119). Coezy E, Borgna JL, Rochefort H. Tamoxifen and metabolites in MCF7 cells: correlation between binding to estrogen receptor and inhibition of cell growth. Cancer Res 1982;42:317-323. [PubMed: 7053859]

(120). Borgna JL, Rochefort H. Hydroxylated metabolites of tamoxifen are formed in vivo and bound to estrogen receptor in target tissues. J. Biol. Chem 1981;256:859-868. [PubMed: 7451477]

(121). Hochner-Celnikier D. Pharmacokinetics of raloxifene and its clinical application. Eur. J. Obstet. Gynecol. Reprod. Biol 1999;85:23-29. [PubMed: 10428318]

(122). Snyder KR, Sparano N, Malinowski JM. Raloxifene hydrochloride. Am. J. Health Syst. Pharm 2000;57:1669-1675. [PubMed: 11006795]quiz 1676-1668

(123). Fiorelli G, Picariello L, Martineti V, Tonelli F, Brandi ML. Estrogen synthesis in human colon cancer epithelial cells. J. Steroid Biochem. Mol. Biol 1999;71:223-230. [PubMed: 10704911]

(124). Buzdar A, O’Shaughnessy JA, Booser DJ, Pippen JE Jr. Jones SE, Munster PN, Peterson P, Melemed AS, Winer E, Hudis C. Phase II, randomized, double-blind study of two dose levels of arzoxifene in patients with locally advanced or metastatic breast cancer. J. Clin. Oncol 2003;21:1007-1014. [PubMed: 12637464]

(125). Sato M, Turner CH, Wang T, Adrian MD, Rowley E, Bryant HU. LY353381.HCl: a novel raloxifene analog with improved SERM potency and efficacy in vivo. J. Pharmacol. Exp. Ther 1998;287:1-7. [PubMed: 9765314]

(126). Kemp DC, Fan PW, Stevens JC. Characterization of raloxifene glucuronidation in vitro: contribution of intestinal metabolism to presystemic clearance. Drug. Metab. Dispos 2002;30:694700. [PubMed: 12019197]

(127). Jordan VC. Metabolites of tamoxifen in animals and man: identification, pharmacology, and significance. Breast Cancer Res. Treat 1982;2:123-138. [PubMed: 6184101]

(128). Liu X, Pisha E, Tonetti DA, Yao D, Li Y, Yao J, Burdette JE, Bolton JL. Antiestrogenic and DNA damaging effects induced by tamoxifen and toremifene metabolites. Chem. Res. Toxicol 2003;16:832-837. [PubMed: 12870885]

(129). Mani C, Hodgson E, Kupfer D. Metabolism of the antimammary cancer antiestrogenic agent tamoxifen. II. Flavin-containing monooxygenase-mediated N-oxidation. Drug. Metab. Dispos 1993;21:657-661. [PubMed: 8104125]

(130). Berthou F, Dreano Y. High-performance liquid chromatographic analysis of tamoxifen, toremifene and their major human metabolites. J. Chromatogr 1993;616:117-127. [PubMed: 8376482]

(131). Yao D, Zhang F, Yu L, Yang Y, van Breemen RB, Bolton JL. Synthesis and reactivity of potential toxic metabolites of tamoxifen analogues: droloxifene and toremifene o-quinones. Chem. Res. Toxicol 2001;14:1643-1653. [PubMed: 11743747]

(132). Sarabia SF, Zhu BT, Kurosawa T, Tohma M, Liehr JG. Mechanism of cytochrome P450-catalyzed aromatic hydroxylation of estrogens. Chem. Res. Toxicol 1997;10:767-771. [PubMed: 9250410]

(133). Spink DC, Zhang F, Hussain MM, Katz BH, Liu X, Hilker DR, Bolton JL. Metabolism of equilenin in MCF-7 and MDA-MB-231 human breast cancer cells. Chem. Res. Toxicol 2001;14:572-581. [PubMed: 11368557]

(134). Zhang F, Chen Y, Pisha E, Shen L, Xiong Y, van Breemen RB, Bolton JL. The major metabolite of equilin, 4-hydroxyequilin, autoxidizes to an o-quinone which isomerizes to the potent cytotoxin 4-hydroxyequilenin-o-quinone. Chem. Res. Toxicol 1999;12:204-213. [PubMed: 10027800]

(135). Shen L, Pisha E, Huang Z, Pezzuto JM, Krol E, Alam Z, van Breemen RB, Bolton JL. Bioreductive activation of catechol estrogen-ortho-quinones: aromatization of the $\mathrm{B}$ ring in 4-hydroxyequilenin markedly alters quinoid formation and reactivity. Carcinogenesis 1997;18:1093-1101. [PubMed: 9163701]

(136). Chen Y, Shen L, Zhang F, Lau SS, van Breemen RB, Nikolic D, Bolton JL. The equine estrogen metabolite 4-hydroxyequilenin causes DNA single-strand breaks and oxidation of DNA bases in vitro. Chem. Res. Toxicol 1998;11:1105-1111. [PubMed: 9760286] 
(137). Shen L, Qiu S, Chen Y, Zhang F, van Breemen RB, Nikolic D, Bolton JL. Alkylation of 2'deoxynucleosides and DNA by the Premarin metabolite 4-hydroxyequilenin semiquinone radical. Chem. Res. Toxicol 1998;11:94-101. [PubMed: 9511900]

(138). Zhang F, Swanson SM, van Breemen RB, Liu X, Yang Y, Gu C, Bolton JL. Equine estrogen metabolite 4-hydroxyequilenin induces DNA damage in the rat mammary tissues: formation of single-strand breaks, apurinic sites, stable adducts, and oxidized bases. Chem. Res. Toxicol 2001;14:1654-1659. [PubMed: 11743748]

(139). Yao J, Chang M, Li Y, Pisha E, Liu X, Yao D, Elguindi EC, Blond SY, Bolton JL. Inhibition of cellular enzymes by equine catechol estrogens in human breast cancer cells: specificity for glutathione S-transferase P1-1. Chem. Res. Toxicol 2002;15:935-942. [PubMed: 12119004]

(140). Li Y, Yao J, Chang M, Nikolic D, Yu L, Yager JD, Mesecar AD, van Breemen RB, Bolton JL. Equine catechol estrogen 4-hydroxyequilenin is a more potent inhibitor of the variant form of catechol-O-methyltransferase. Chem. Res. Toxicol 2004;17:512-520. [PubMed: 15089093]

(141). Yao J, Li Y, Chang M, Wu H, Yang X, Goodman JE, Liu X, Liu H, Mesecar AD, Van Breemen RB, Yager JD, Bolton JL. Catechol estrogen 4-hydroxyequilenin is a substrate and an inhibitor of catechol-O-methyltransferase. Chem. Res. Toxicol 2003;16:668-675. [PubMed: 12755597]

(142). Zhang Z, Chen Q, Li Y, Doss GA, Dean BJ, Ngui JS, Silva Elipe M, Kim S, Wu JY, Dininno F, Hammond ML, Stearns RA, Evans DC, Baillie TA, Tang W. In vitro bioactivation of dihydrobenzoxathiin selective estrogen receptor modulators by cytochrome P450 3A4 in human liver microsomes: formation of reactive iminium and quinone type metabolites. Chem. Res. Toxicol 2005;18:675-685. [PubMed: 15833027]

(143). Sanchez C, Shibutani S, Dasaradhi L, Bolton JL, Fan PW, McClelland RA. Lifetime and reactivity of an ultimate tamoxifen carcinogen: The tamoxifen carbocation. J. Am. Chem. Soc 1998;120:13513-13514. 
A)<smiles>CC/C(=C(/c1ccccc1)c1ccccc1/C(CC)=C(\c1ccccc1)c1ccc(OCCN(C)C)cc1)c1cccc(OCCN(C)C)c1</smiles><smiles>CN(C)CCOc1ccc(C(=C(CCCl)c2ccccc2)c2ccccc2)cc1</smiles>

Tamoxifen (Nolvadex)

Droloxifene

Toremifene (Fareston)<smiles>CC/C(=C(\c1ccc(I)cc1)c1ccc(OCCN2CCCC2)cc1)c1ccccc1</smiles>

Idoxifene

B)

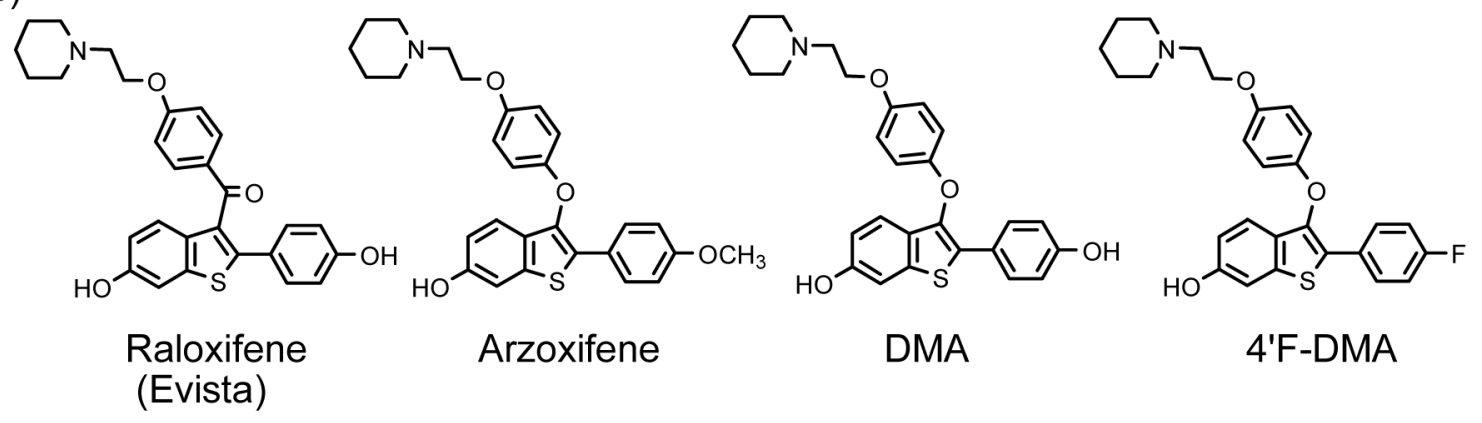

C)<smiles>CC1=C(c2ccc(OC(=O)C(C)(C)C)cc2)[C@@H](c2ccc(OCCN3CCCCC3)cc2)Oc2cc(OC(=O)C(C)(C)C)ccc21</smiles>

EM-800<smiles>CC1=C(c2ccc(O)cc2)C(c2ccc(OCCN3CCCCC3)cc2)Oc2cc(O)ccc21</smiles>

EM-652 (Acolbifene)

Figure 1. Chemical Structures of SERMs

A) Triphenylethylene SERMs; B) Benzothiophene SERMs; C) Benzopyran SERMs 
A)<smiles>O=C(CCCC1SCC2NC(=O)NC21)NCCCCCC(=O)NCCOc1ccc(C(=O)c2c(-c3ccc(O)cc3)sc3cc(O)ccc23)cc1</smiles>

B)

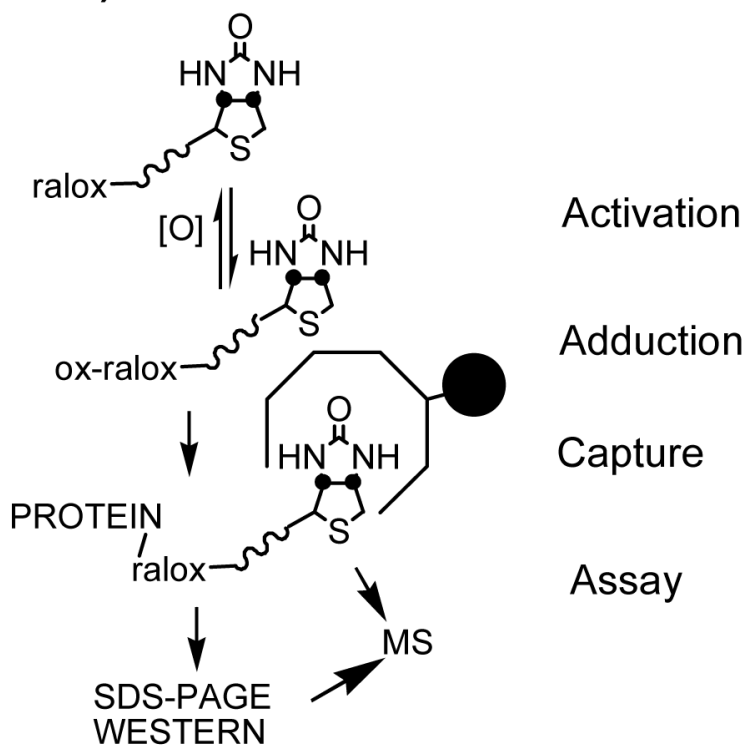

Figure 2. Analysis of Raloxifene COATag Modified Proteins

A) Structure of the raloxifene covert oxidatively activated tag (COATag) in which raloxifene is linked to biotin (62). B) Identification of covalently modified proteins by the raloxifene COATag was achieved by immunoblotting and LC-MS-MS analysis (62). 


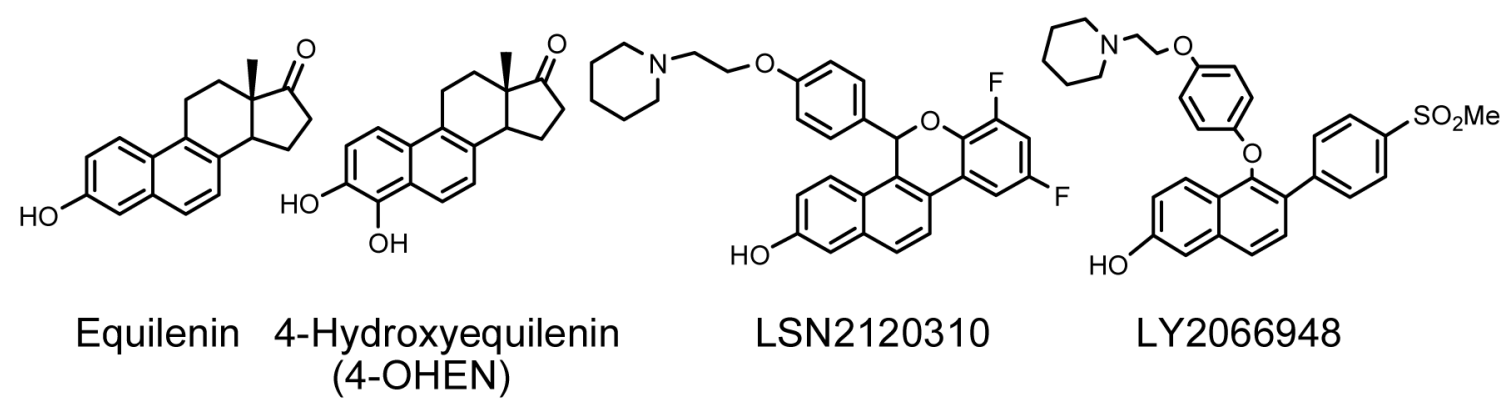

Figure 3. Chemical Structures of Naphthol SERMs and Equine Estrogens Naphthol SERMs LY2066948 and LSN2120310 are similar in structure to the equine estrogen equilenin. Equilenin is hydroxylated by $\mathrm{P} 450$ on the B-ring to form 4-hydroxyequilenin $(132,133)$. 


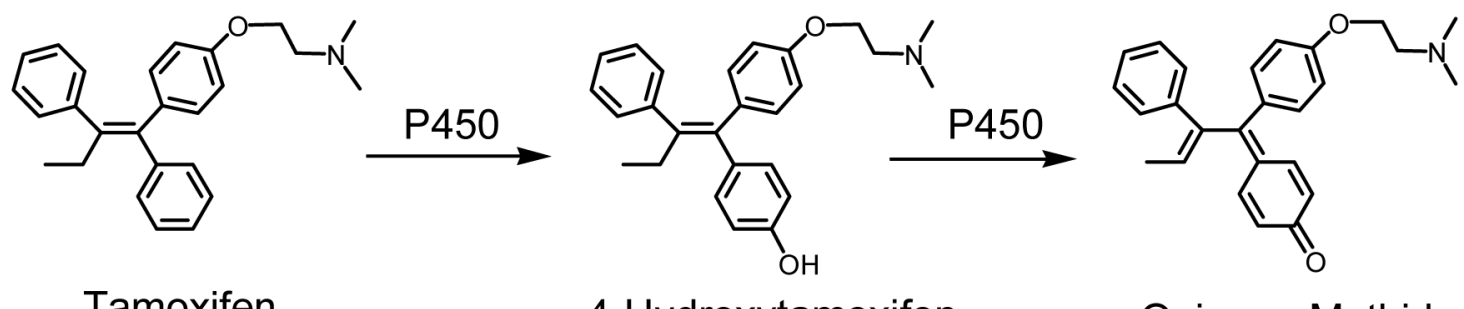

Tamoxifen

4-Hydroxytamoxifen

Quinone Methide

$\downarrow$ 1) P450 PAPS/Sulfotransferase $\downarrow$ P450<smiles>CC(O)C(C1=CC=CC1)=C(c1ccccc1)c1ccc(OCCN(C)C)cc1</smiles>

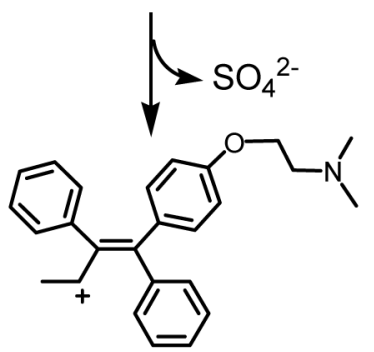

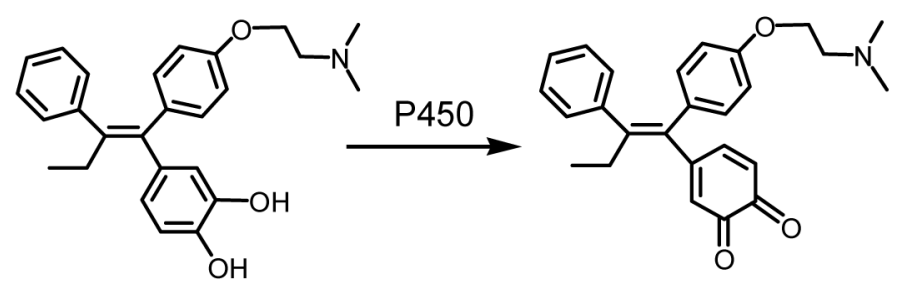

3,4-Dihydroxytamoxifene

o-Quinone

\section{Carbocation}

Scheme 1. Bioactivation of Tamoxifen

Tamoxifen is hydroxylated by $\mathrm{P} 450$ to form 4-hydroxytamoxifen, which can be converted to a quinone methide via a 2-electron oxidation mechanism (11). Alternatively, 4hydroxytamoxifen can be further hydroxylated at the 3 position to produce 3,4dihydroxytamoxifen, which can then be oxidized to the $o$-quinone (10). The tamoxifen carbocation is formed by initial $\alpha$-hydroxylation followed by $O$-sulfonation and subsequent sulfate dissociation (8). 


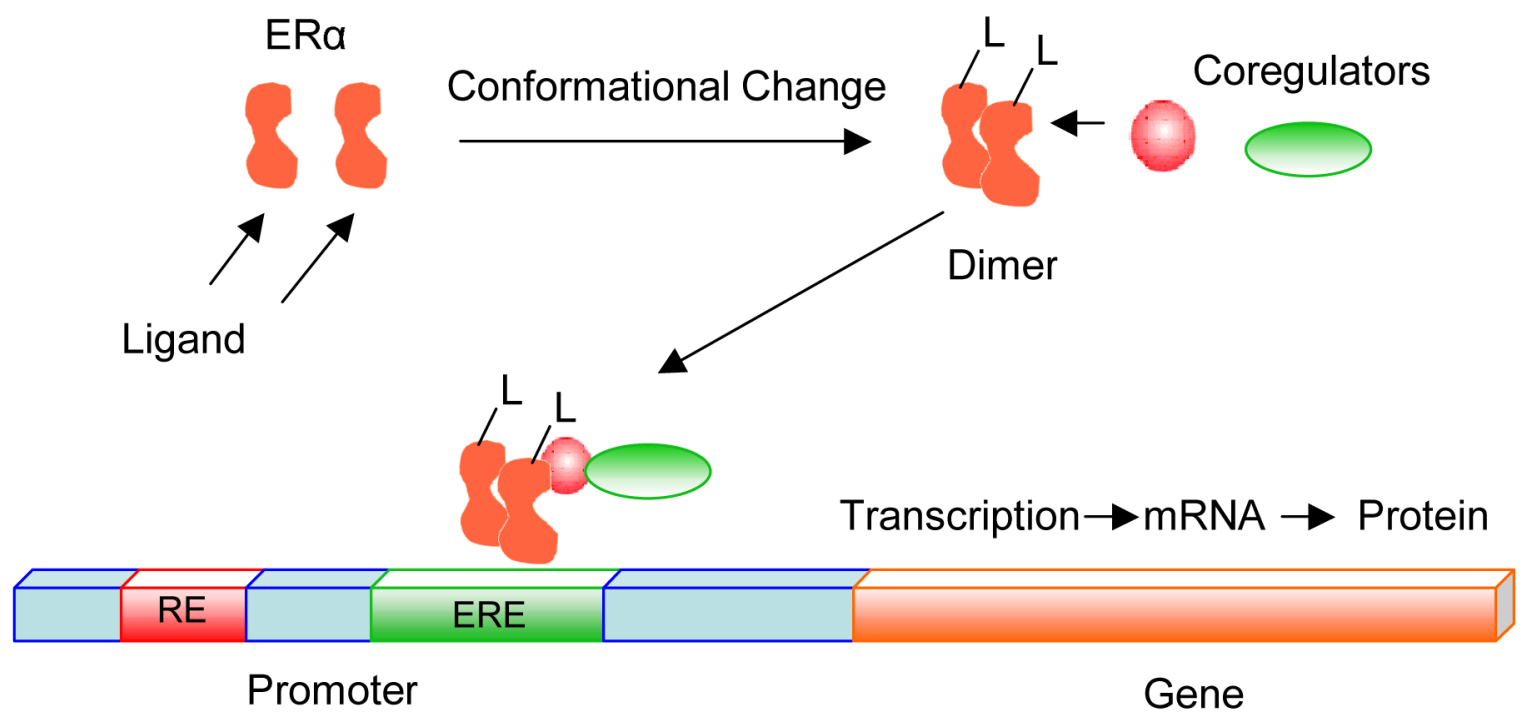

DNA

Scheme 2. Ligand-Dependent Transcriptional Activation by the ER

Ligands put forth their regulatory effects by binding to ERs, which induces conformational changes in protein structure that allow for receptor dimerization and interaction with coactivator molecules $(20,21)$. Coregulators associate in a ligand-dependent manner with the ER. Coactivators enhance ligand-dependent transcriptional activation by the $\operatorname{ER} \alpha(48,49)$. 
<smiles>C=C1C(=C2C=CC(=O)C=C2)[C@@H](c2ccc(OCCN3CCCCC3)cc2)Oc2cc(O)ccc21</smiles><smiles>CC1=C2C=CC(=O)C=C2O[C@@H](c2ccc(OCCN3CCCCC3)cc2)C1=C1C=CC(=O)C=C1</smiles>

Diquinone Methide

Scheme 3. Bioactivation of Acolbifene

Acolbifene is converted to both a classical quinone methide and a diquinone methide by $\mathrm{P} 450$ (59). 

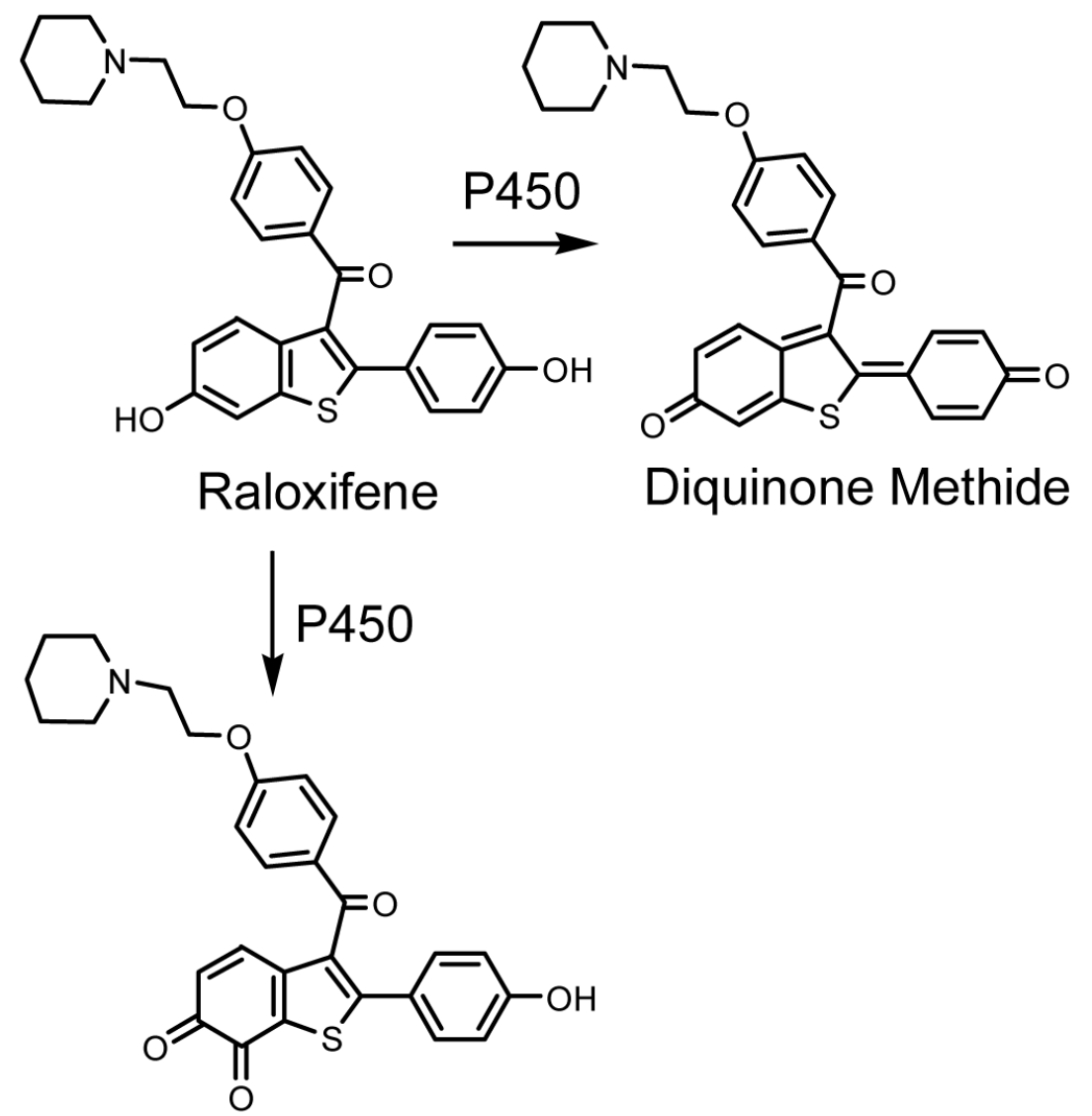

\section{o-Quinone}

Scheme 4. Bioactivation of Raloxifene

Raloxifene is oxidized by $\mathrm{P} 450$ to produce a diquinone methide and an $o$-quinone (60). 


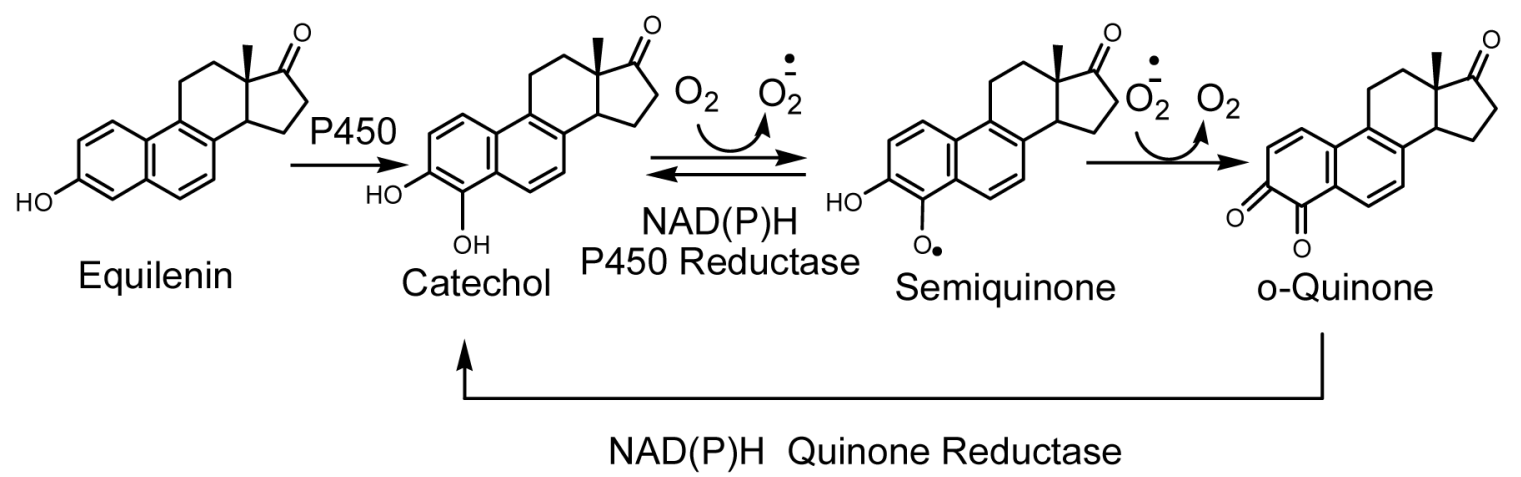

\section{Scheme 5. Bioactivation of Equilenin}

P450s catalyze the exclusive 4-hydroxylation of equilenin and the catechol formed can autooxidize to the 3,4-o-quinone via a semiquinone intermediate (134). Catalyzed by NAD(P)H, $\mathrm{P} 450$ reductase, or quinone reductase, the $o$-quinone readily enters into a redox couple with the semiquinone radical, resulting in the generation of reactive oxygen species (ROS) (135). 


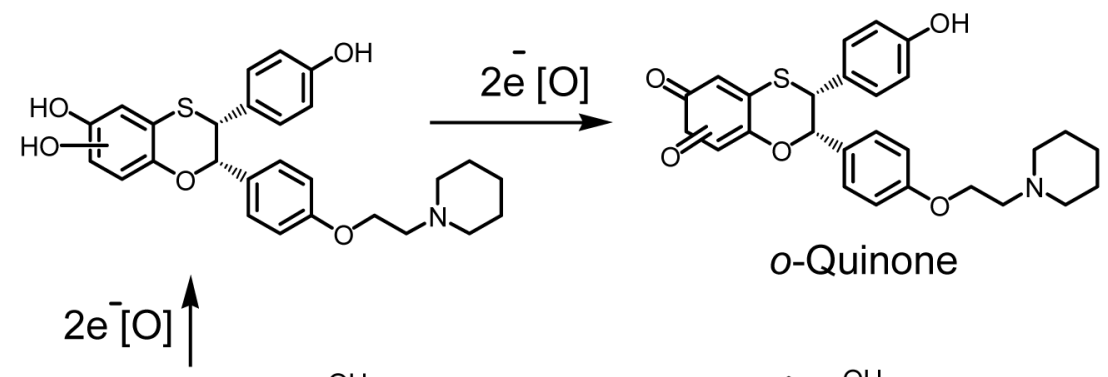

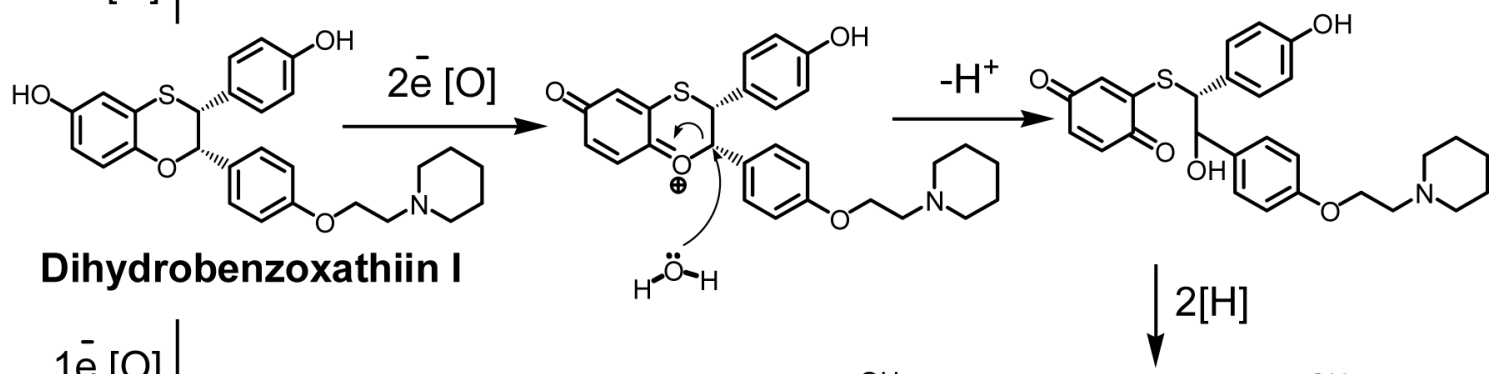<smiles>CCOc1ccc(C(O)C(Sc2cc(O)ccc2C(O)c2ccc(O)cc2)c2ccc(O)cc2)cc1</smiles>

Scheme 6. Reactive Metabolite Formation from Dihydrobenzoxathiin I

Three bioactivation pathways were observed when dihydrobenzoxathiin I was incubated with human liver microsomes and recombinant P450 3A4. Oxidative cleavage of the dihydrobenzoxathiin moiety led to the formation of a hydroquinone. Phenol hydroxylation at either ortho position followed by further oxidation formed an $o$-quinone. Additionally, an iminium ion intermediate was formed on the piperidine side chain (142). 
<smiles>CC1(C)CCCC1</smiles><smiles>O=Cc1ccc(OCCN2CCCC2)cc1</smiles>

Aldehyde $1 \overline{\mathrm{e}}[\mathrm{O}] \uparrow$

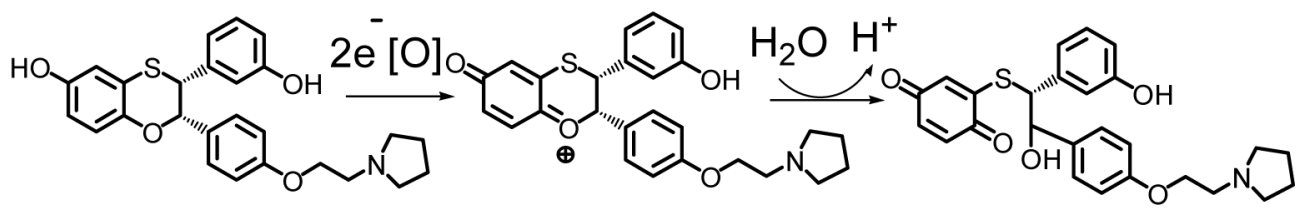
Dihydrobenzoxathiin II<smiles>O=C1C=CC2=C(SC(O)C(O)c3ccc(OCCN4CCCC4)cc3)C(=O)C=CC2=C1</smiles><smiles>O=C1C=CC2=C3C=CC(=O)C=C3C(C(O)c3ccc(OCCN4CCCC4)cc3)C2=C1</smiles><smiles>O=C1C=CC(=O)C(SSC(c2ccc(OCCN3CCCC3)cc2)C(O)c2cccc(O)c2)C1</smiles><smiles>C=C[TeH]</smiles>

\section{Quinone Methide}<smiles>Oc1ccc2c(c1)SC(C(O)c1ccc(OCCN3CCCC3)cc1)c1cc(O)ccc1-2</smiles>

\section{Hydroquinone}

\section{Extended Biphenyl Hydroquinone}

Scheme 7. Reactive Metabolite Formation from Dihydrobenzoxathiin II

Dihydrobenzoxathiin II was incubated with human liver microsomes and recombinant P450 3A4. The major metabolite biphenyl hydroquinone resulted from the rearrangement of the parent compound. Oxidative cleavage of the dihydrobenzoxathiin moiety led to the formation of hydroquinone. A reactive aldehyde metabolite was also detected (142). 
Table 1

Relative Reactivities of SERM Intermediates

\begin{tabular}{lcc}
\hline SERM metabolite & Half-life $^{\boldsymbol{a}}$ & Reference \\
\hline Tamoxifen Quinone Methide $^{b}$ & $3 \mathrm{~h}$ & $(11)$ \\
Tamoxifen 3,4- $o$-Quinone $^{c}$ & $80 \mathrm{~min}$ & $(10)$ \\
Toremifene Quinone Methide $^{b}$ & $60 \mathrm{~min}$ & $(11)$ \\
Raloxifene 6,7-o-Quinone $^{b}$ & $69 \mathrm{~min}$ & $(60)$ \\
Acolbifene Quinone Methide $^{b}$ & $32 \mathrm{~s}$ & $(59)$ \\
DMA Diquinone Methide $b$ & $15 \mathrm{~s}$ & $(61)$ \\
Raloxifene Diquinone Methide $^{b}$ & $<1 \mathrm{~s}$ \\
Tamoxifen Carbocation $^{d}$ & $22 \mu \mathrm{s}^{e}$ \\
\hline
\end{tabular}

${ }^{a}$ Approximate half-life.

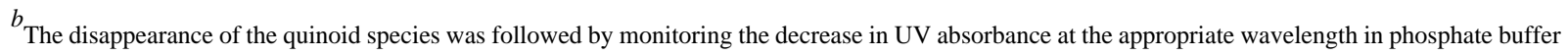
$\left(\mathrm{pH} 7.4,37^{\circ} \mathrm{C}\right)(11,59,60,61)$.

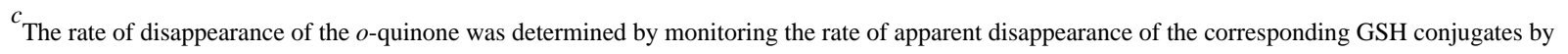
HPLC (10).

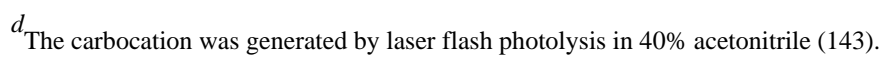

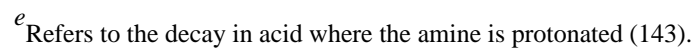

